\title{
تمازج العلاقة في النص وتداخلها بين المرسِل والمرسلَ إليه - بلاغة البمهور نموذجا
}

The relationship in the text mixes and overlaps between the sender and the addressee - public rhetoric as a model

\section{sleel}

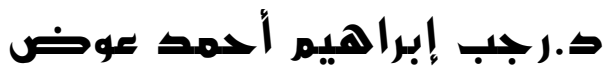

أستاذ مساعد بكلية اللغة العربية جامعة السلطان عبد الحليم معظم شاه الإسلامية العالمية

Doi: 10.12816/mdad.2020.122951

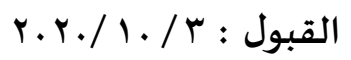

الاستلام: r. r. r/9/9

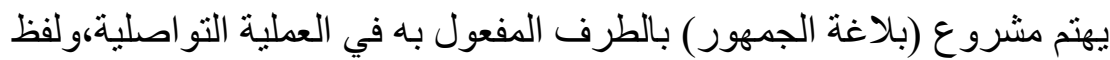

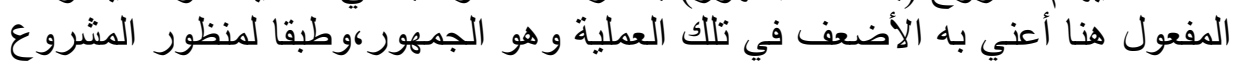

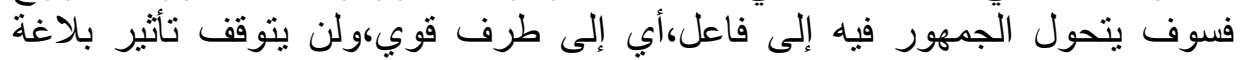

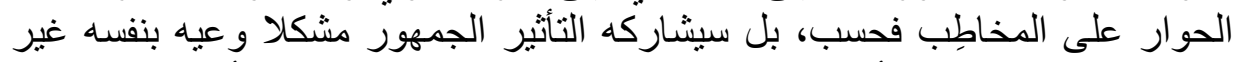

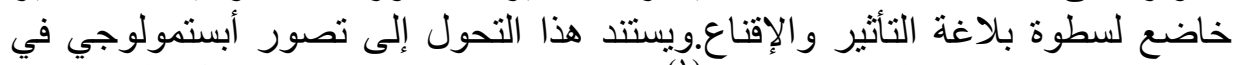

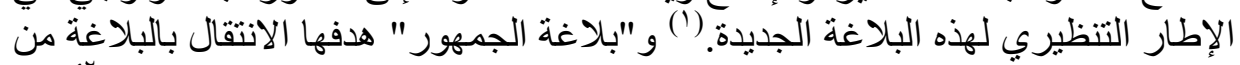

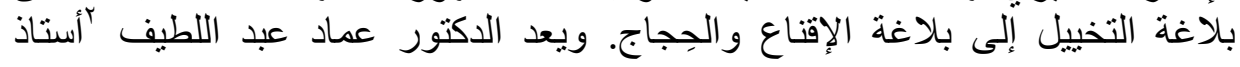

(') الأبستيمولوجيا:علم المعرفيات أو نظرية المعرفة،هو هي فرع من فروع الفلسفة تهتم بطبيعة ومجال المعرفة.

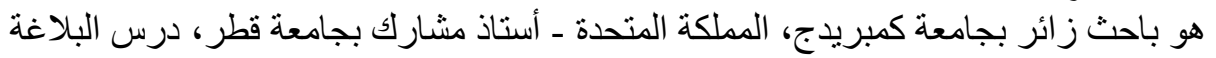

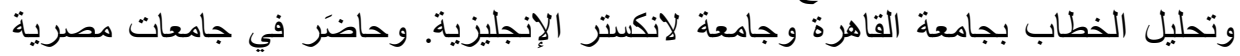

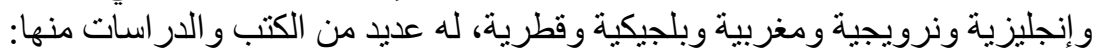

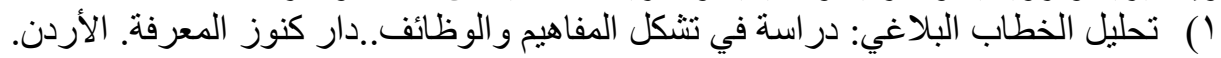
$(Y+1 \varepsilon)$ r) "بلاغة الحرية: معارك الخطاب السياسي في زمن الثورة". دار التنوير، بيروت_القاهرة-

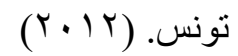
r) استراتيجيات (Yإلقناع والتأثثر في الخطاب السياسي.). العيئة العامة للكتاب، القاهرة. $\wedge 9$ 
البلاغة وتحليل الخطاب بجامعة القاهرة صاحب الفضل في نشر تلك البلاغة عربيا حين

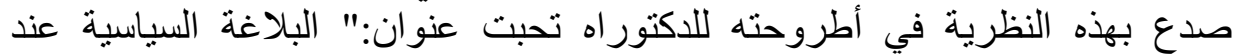

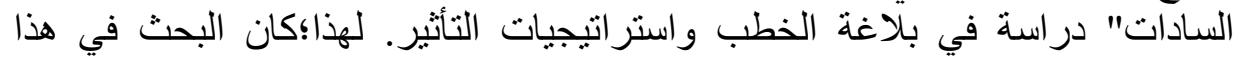

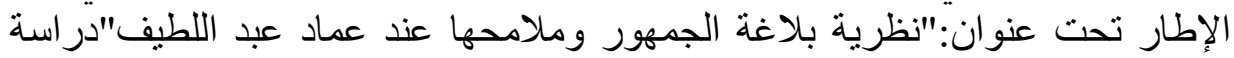

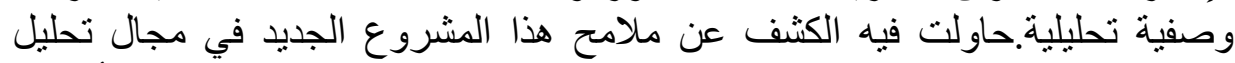

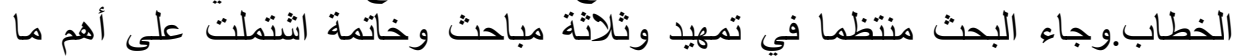

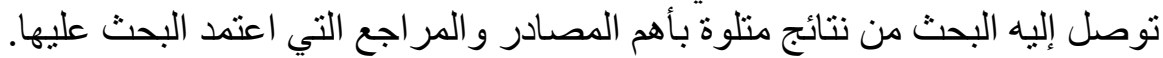

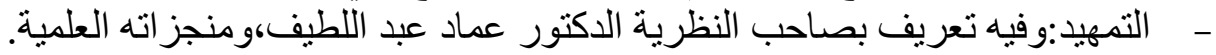

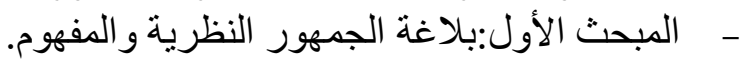

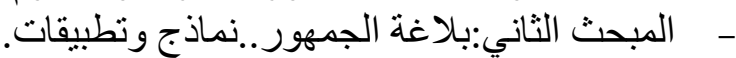

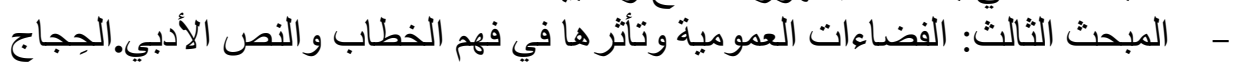
نموذجا. - الخاتمة:وا اشتملت على أهم ما توصل إليه البحث من نتائج متلوة بأهم المصادر و المر اجع التي اعتمد البحث علئها.

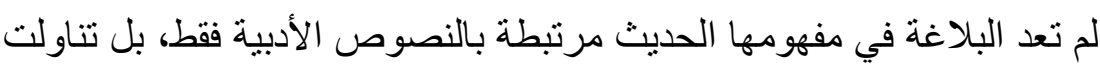

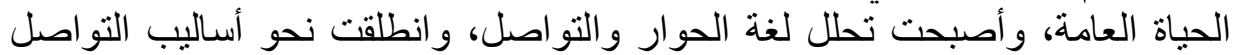
و الاتصال تحاول أن تؤصل لهاهـ

ع) البلاغة و التو اصل عبر الثقافات. سلسلة كتابات نقدية، العيئة العامة لقصور الثقافة، القاهرة. (Y. I r)

0) لماذا يصفق المصريون؟ بلاغة التناعب بالجماهير في السياسة والفن.. دار العين، القاهرة. (Y...9)

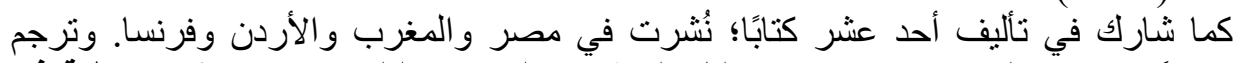

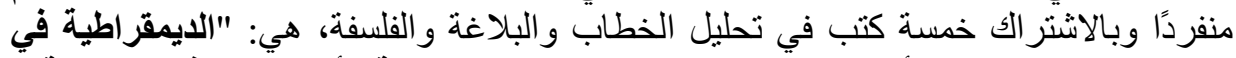

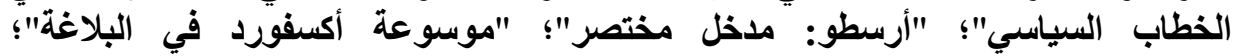

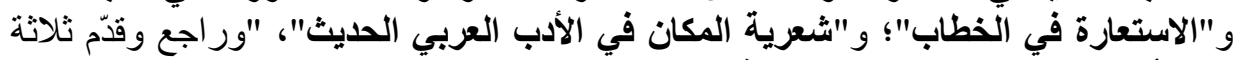

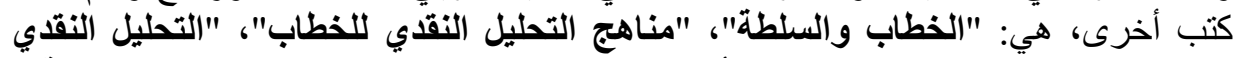

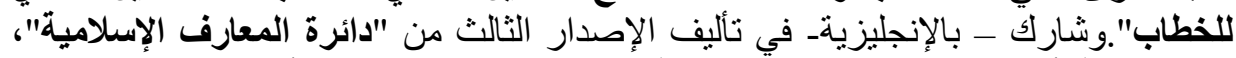

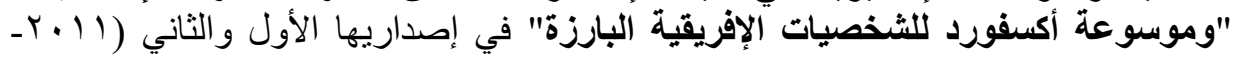


ومن بين هذه الاستعمالات البلاغية للبلاغة الجديدة، بلاغة الجمهور، وقد كان الذان الذهان

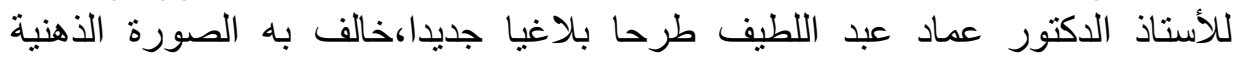

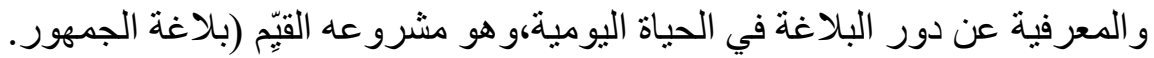

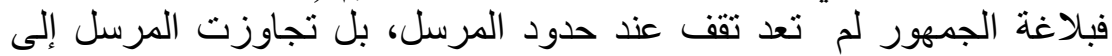

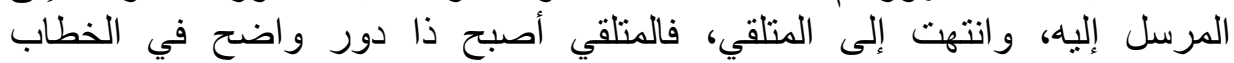

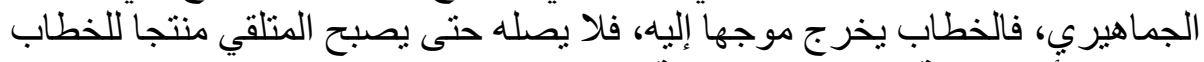

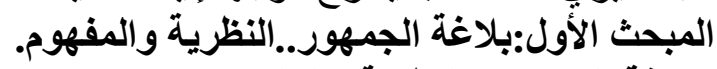

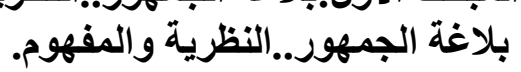

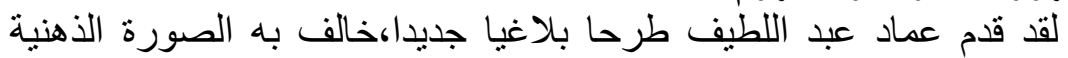

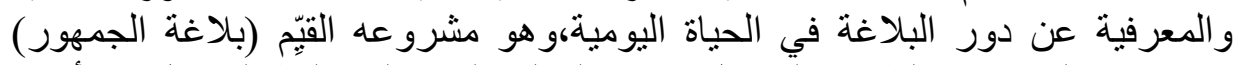

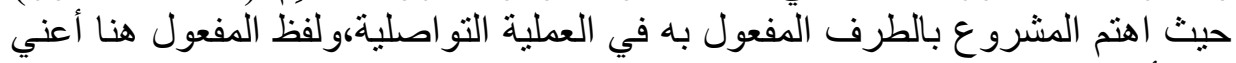

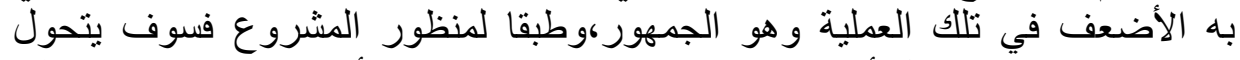

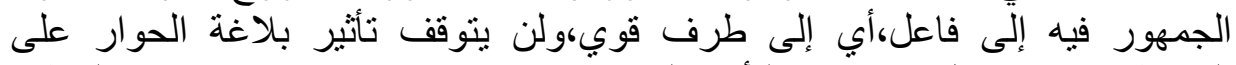

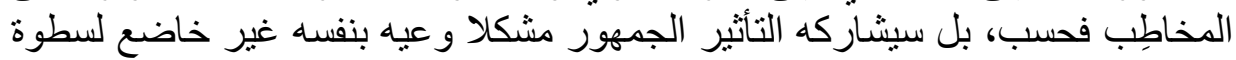

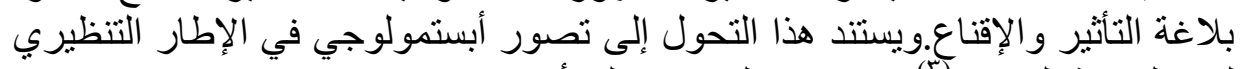

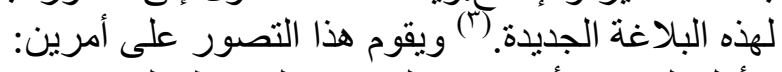
الأول:البحث الأكاديمي والمعرة آلوفي المرتبط بالدر استات الأكاديمية سو اء الأبستمولوجية أو الفلسفية.

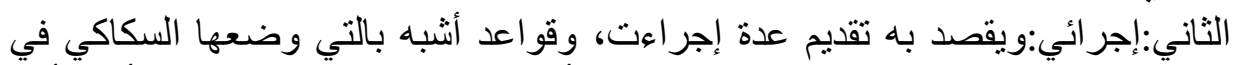

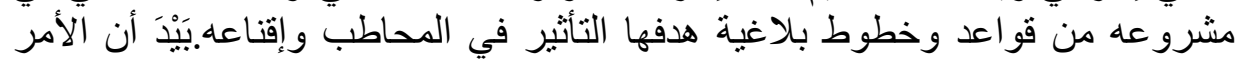

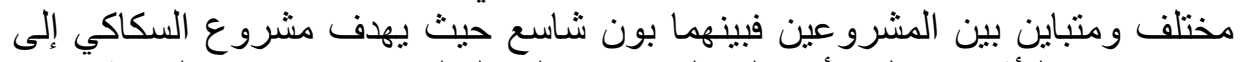

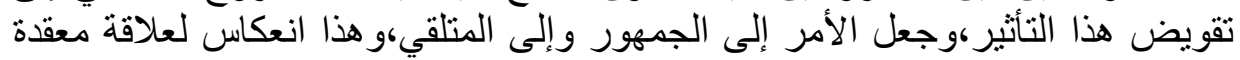

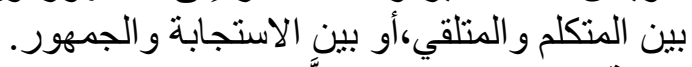

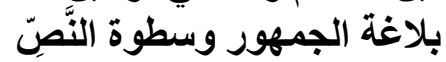

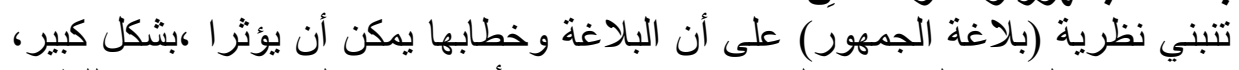

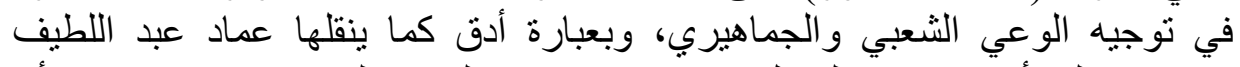

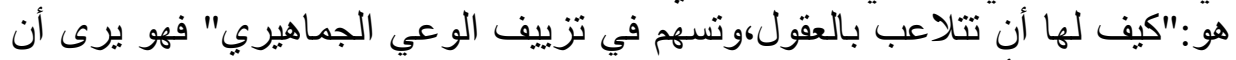

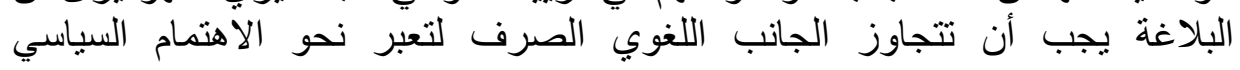

(T) الأبستيمولوجيا:علم المعرفيات أو نظرية المعرفة،هوهي فرع من فروع الفلسفة تهتم بطبيعة 
و الاجتماعي،والنظر في كيفيات وآليات تشكيل الوعي الجماهيري؛ليدرك كيف يتم

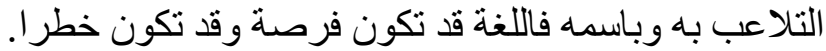

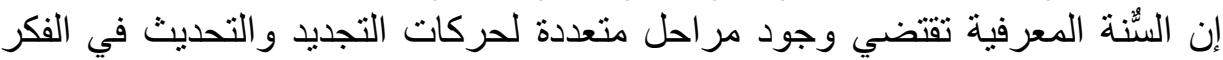

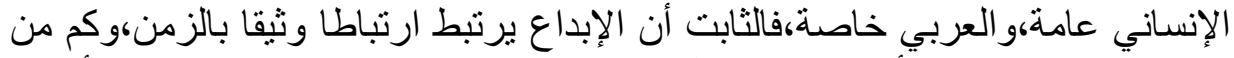

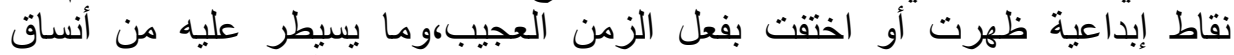

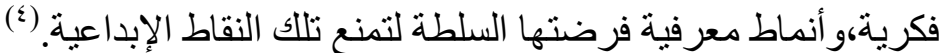

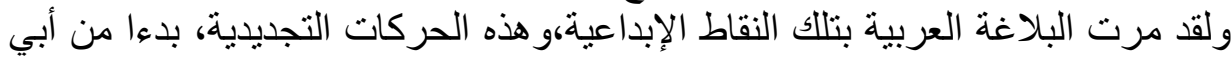

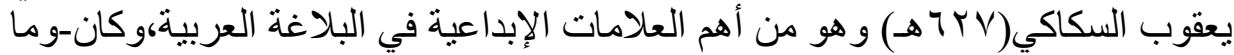

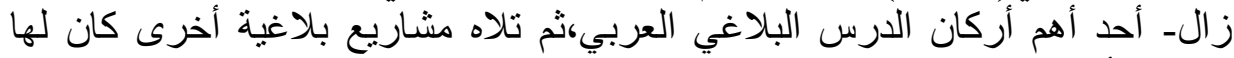

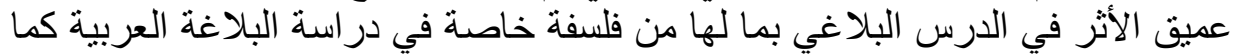

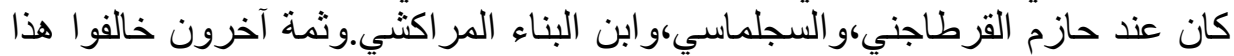

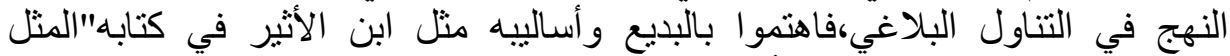

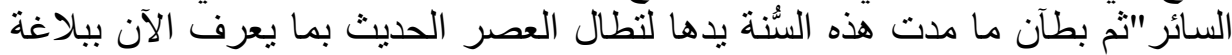

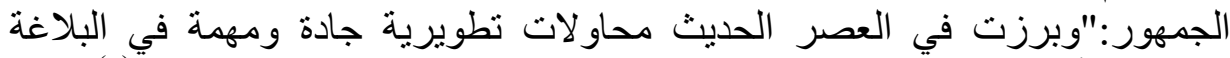

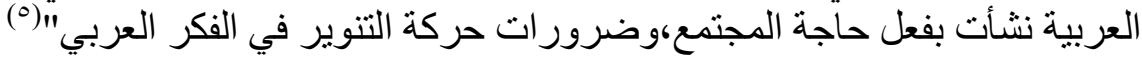
بلاغة الجمهور وخصوصية التواصل. فئل

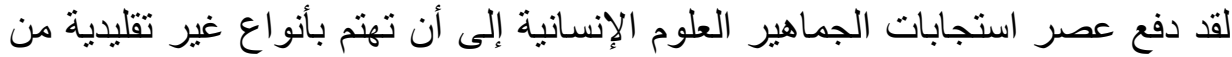

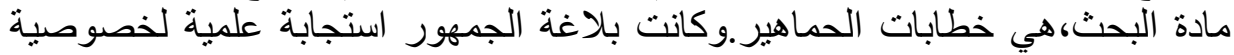

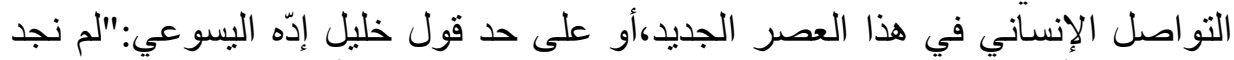

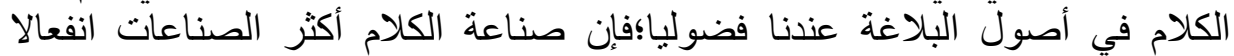

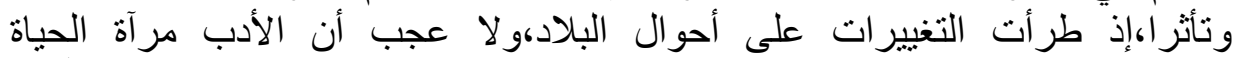

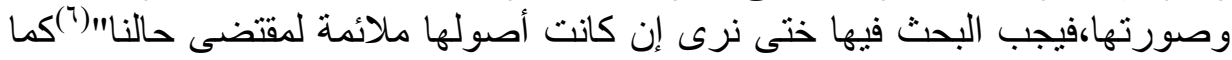

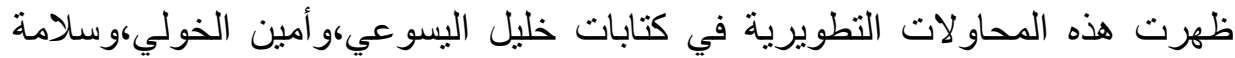

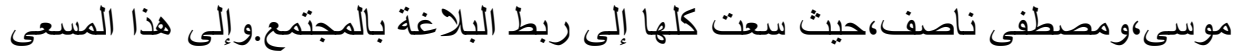

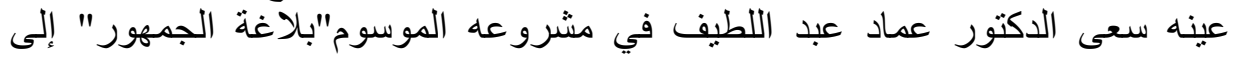

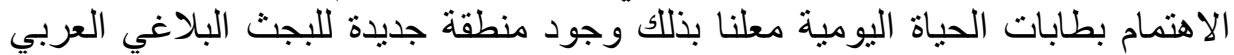

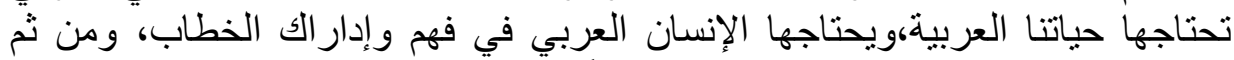

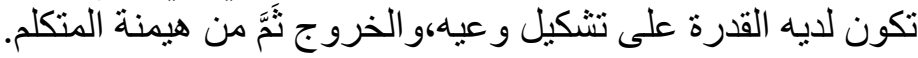

() صلاح حاوي،و عبد الوهاب صديقي،بلاغة الجمهور .ص • ( ـبتصرف يسير. ( ) (السابق. (1)

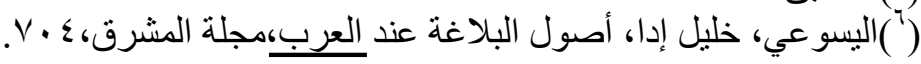


إن اهتمامه منصرف_في مقامه الأول- إلى دراسة رد فعل الجمهور، أو الاستجابات

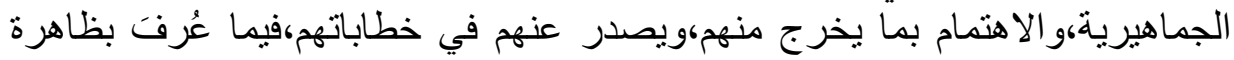

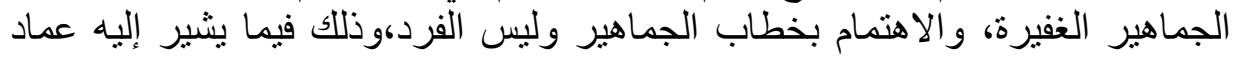

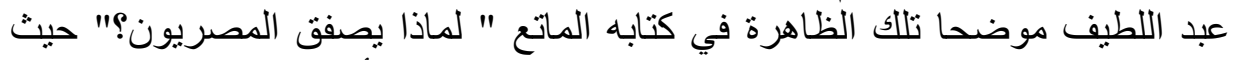

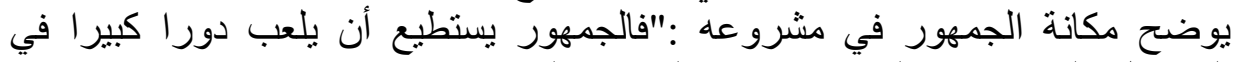

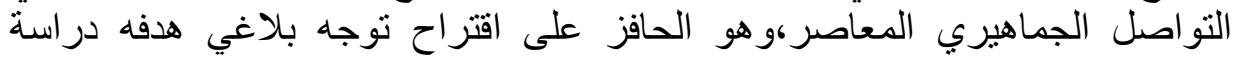

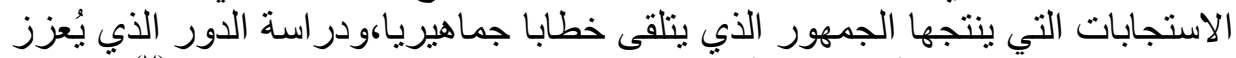

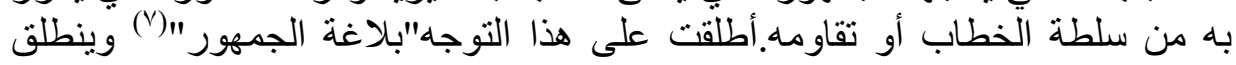

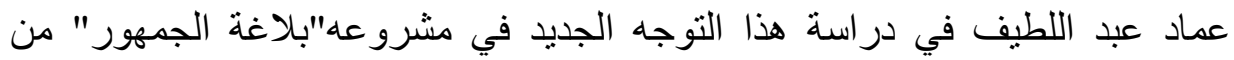

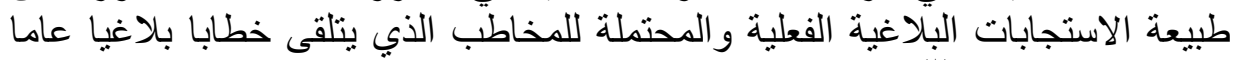

$$
\text { موضو عا لدر استها" (^). }
$$

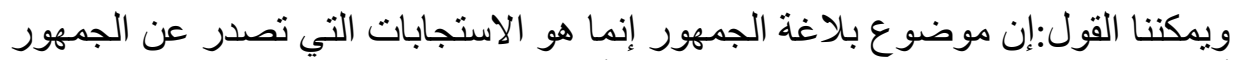

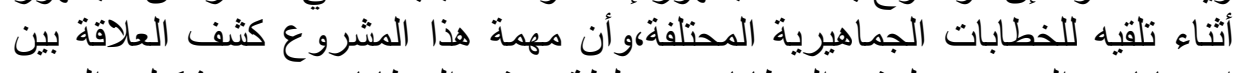

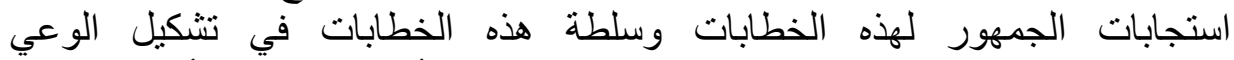

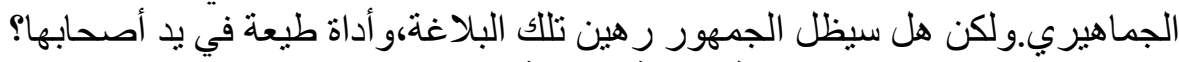

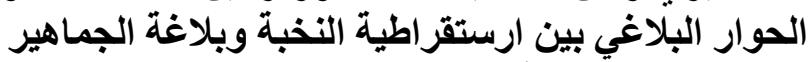

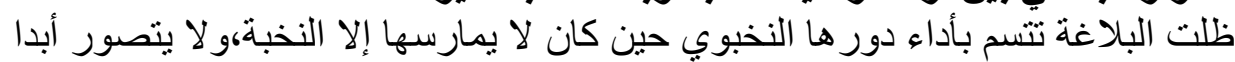

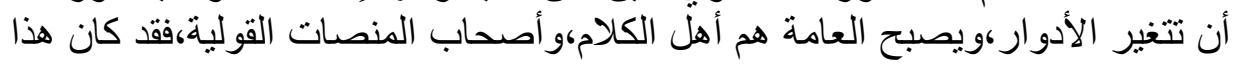

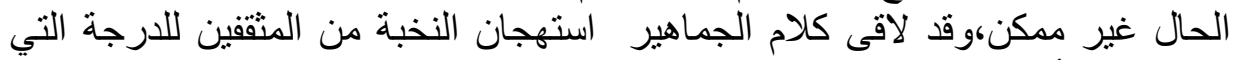

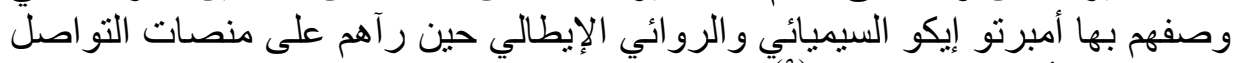

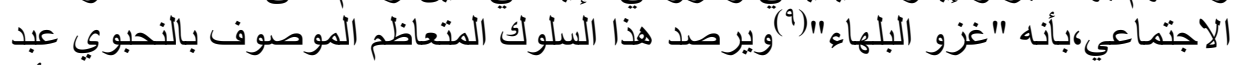

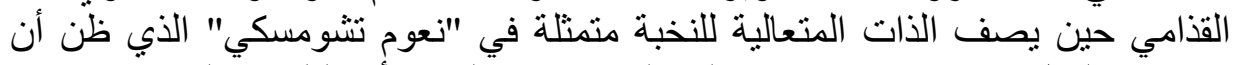

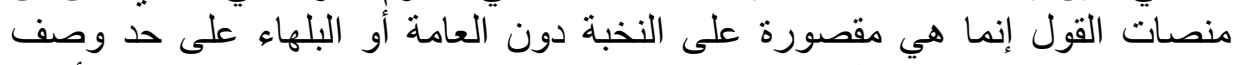

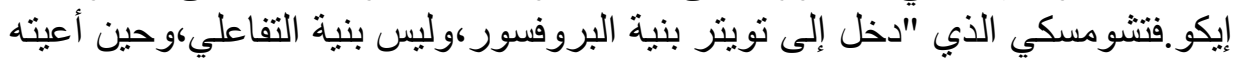

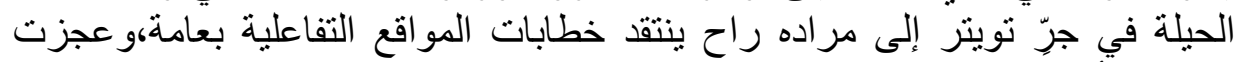
نخبويته أن تفتح عينيها على المتغير الثقافي النوعي بانكسار زمن النخبة وثنافة بعانة

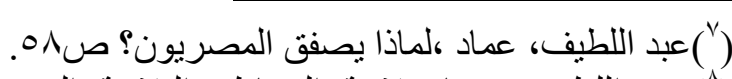

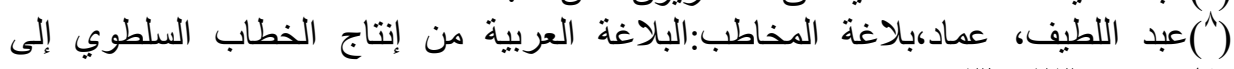

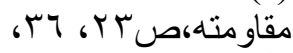

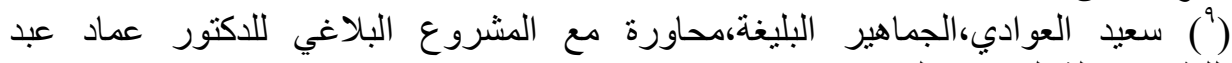

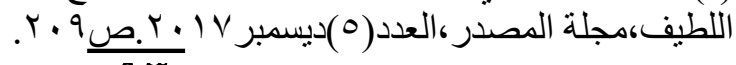


النخبة،وبروز الثعبي بقوته العددية والثقافية ذات المزاج المختلف"(·) لويأني

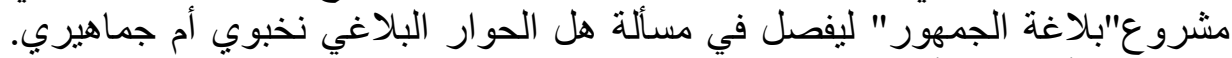

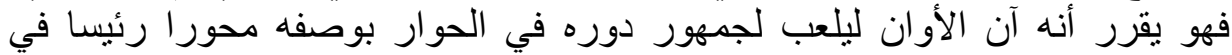

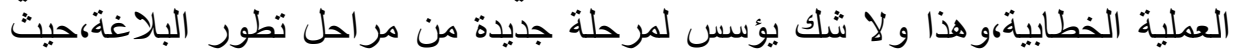

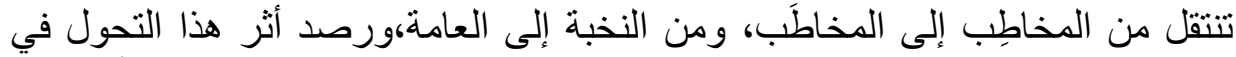

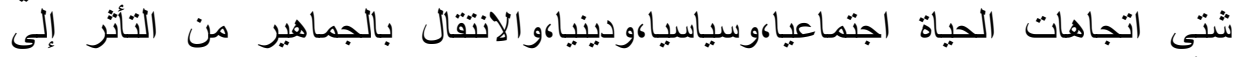
التأثير .وتلك هي روح البلاغة الحقيقية وغايتها المقصودة التصائ

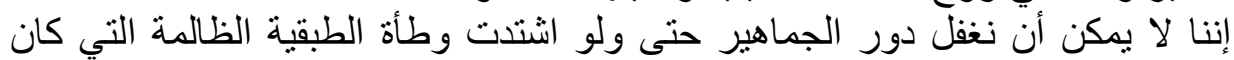

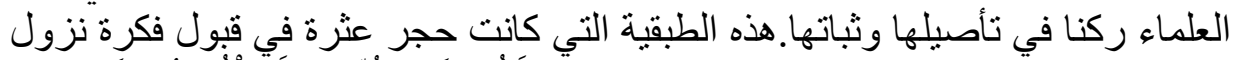

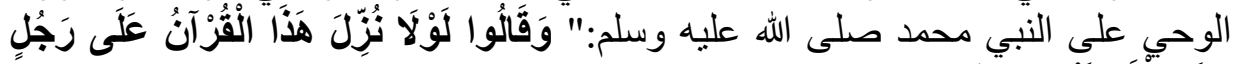

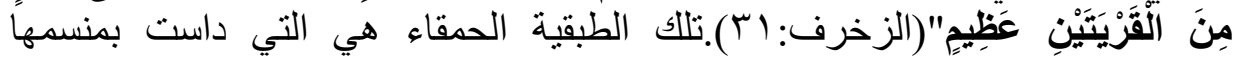

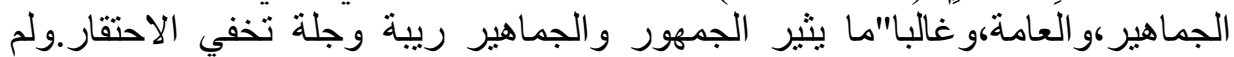

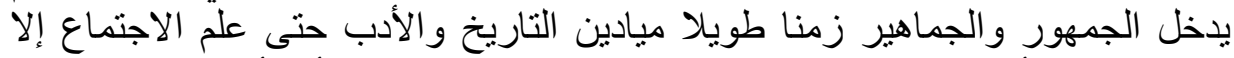

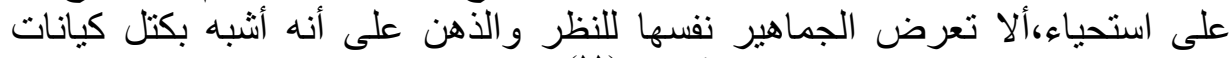

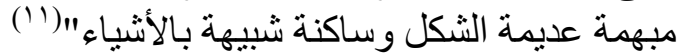

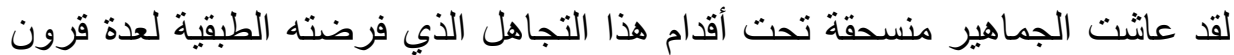

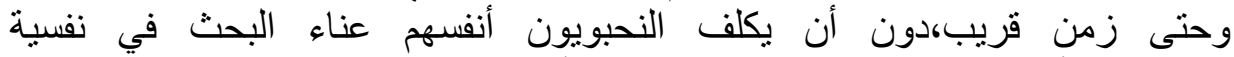

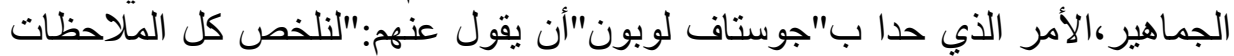

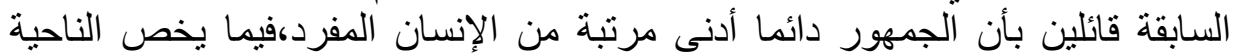

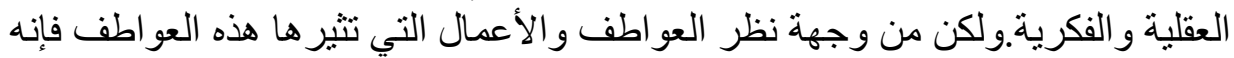

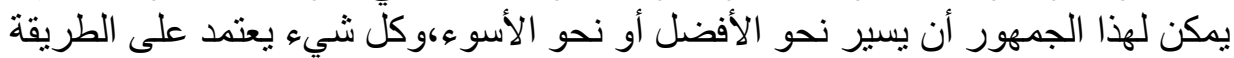

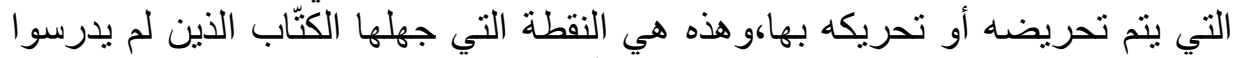

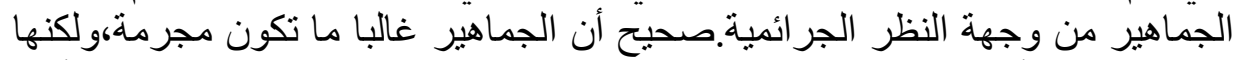

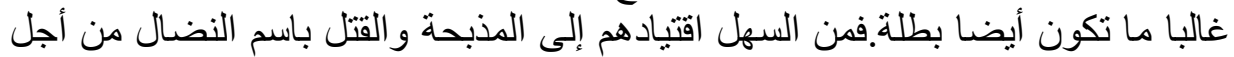

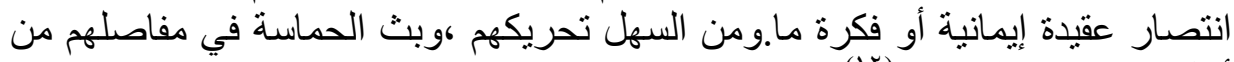

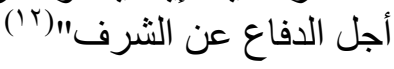

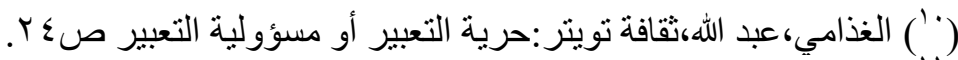

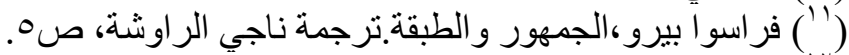

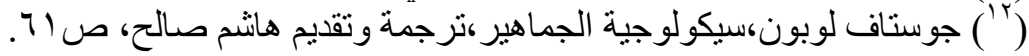


وفي السياق ذاته يقول سيجموند فرويد عن الجمهور:"الجمهور سريع النأثر،سريع

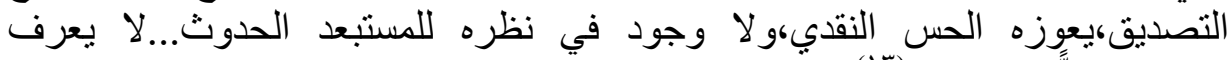

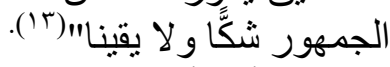

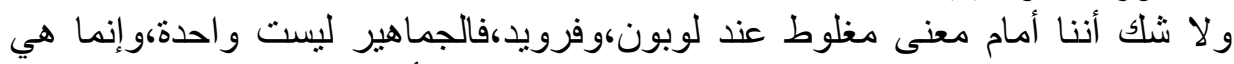

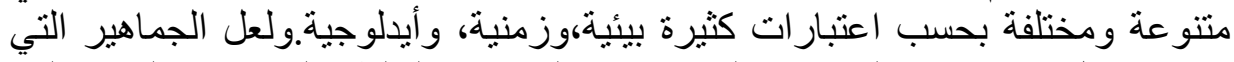

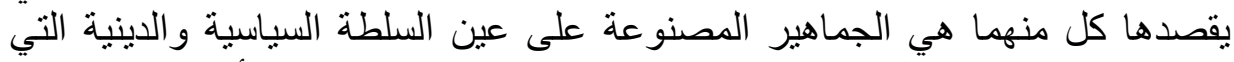

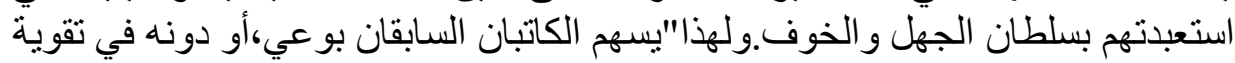

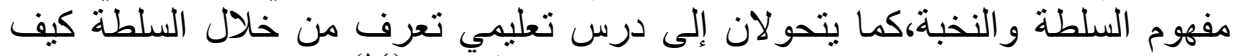

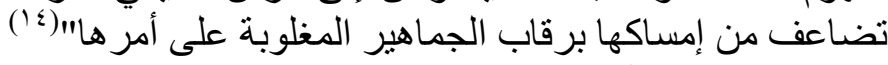

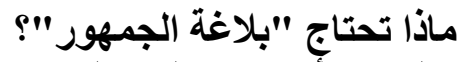
والحقيقة أنه يمكن لهذا الجمهور الجهور الفكالك من أسر المتكلم حين يمتلك أدواته،فتكون له له

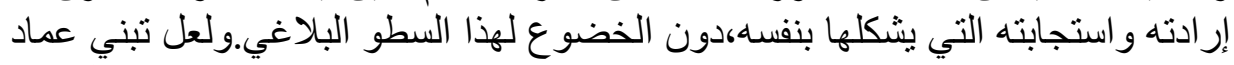

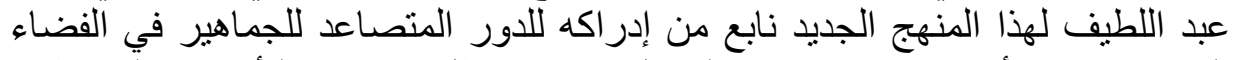

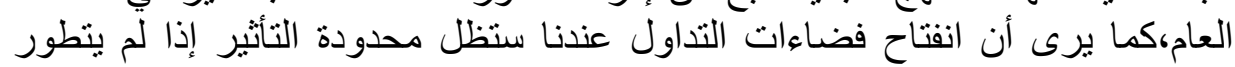

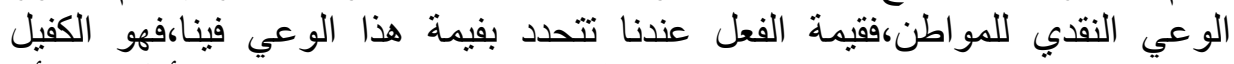

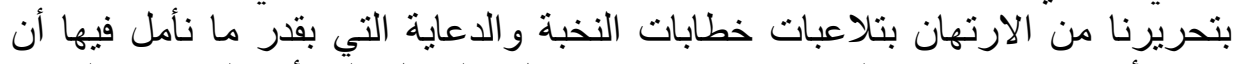

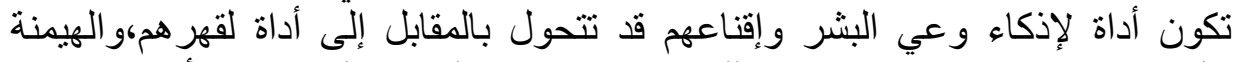

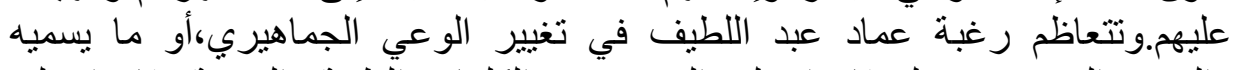

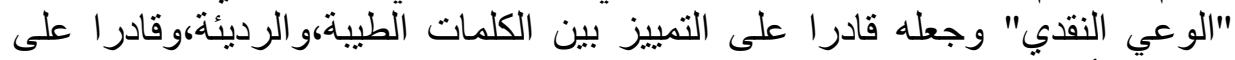

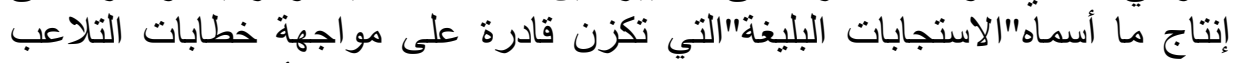

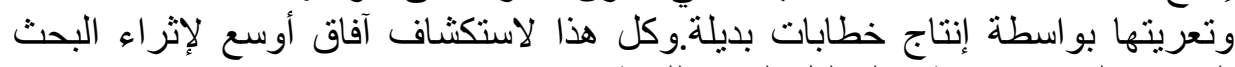

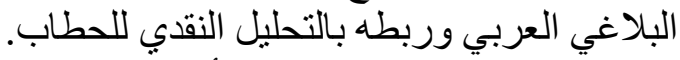

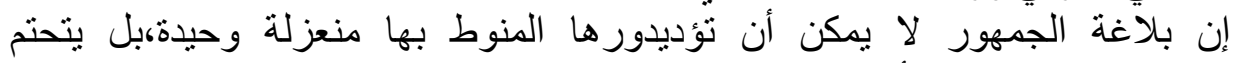

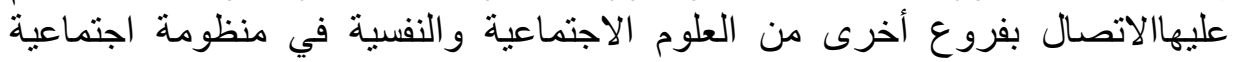

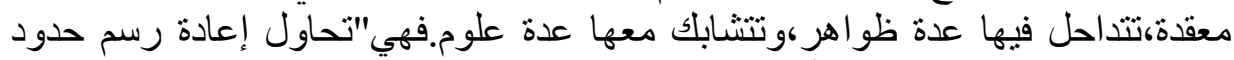

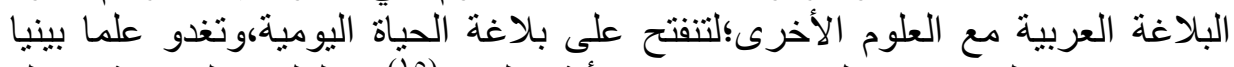

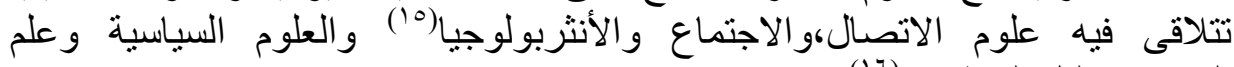
النفس،وتحليل الخطاب" (17)

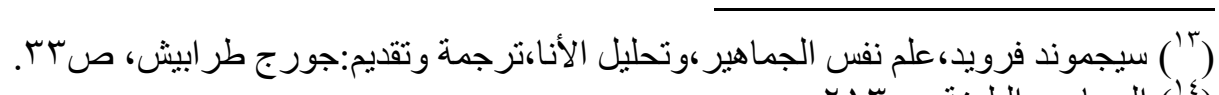

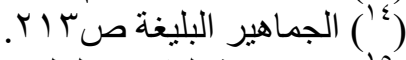

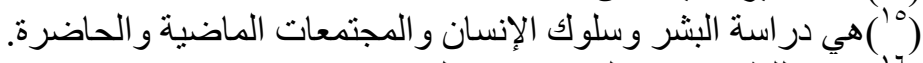

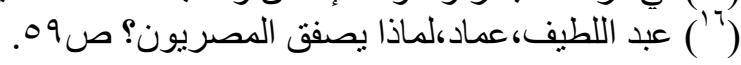
90 
تالثا:ملامح مشروع "بلاغة الجمهور مثرب

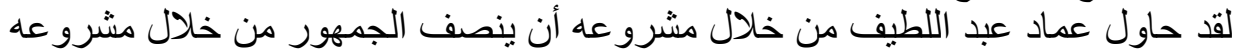

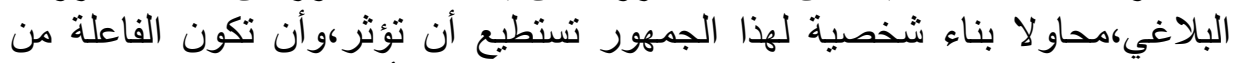

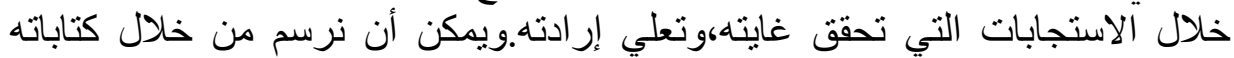

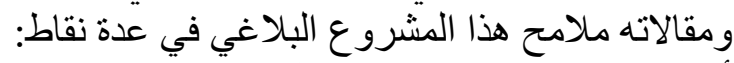

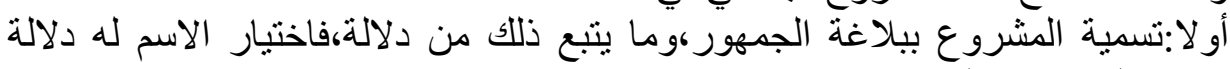

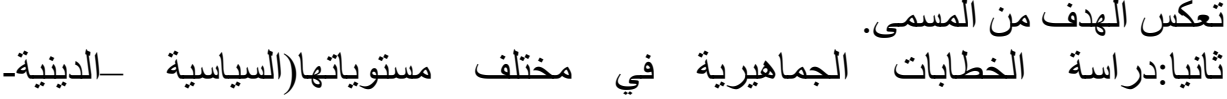

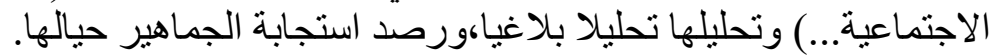

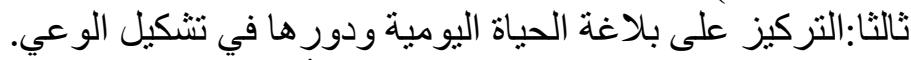

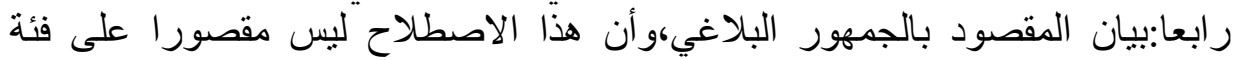

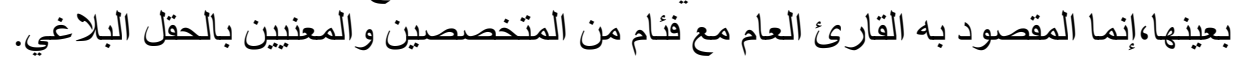

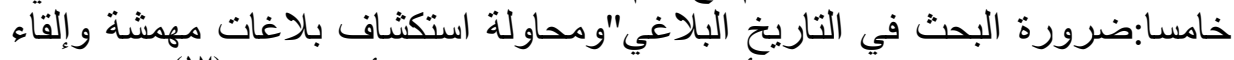

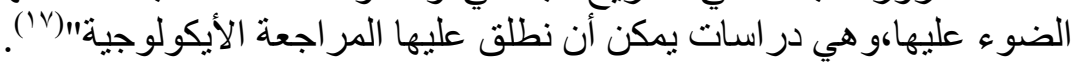

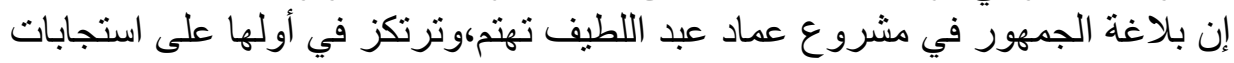

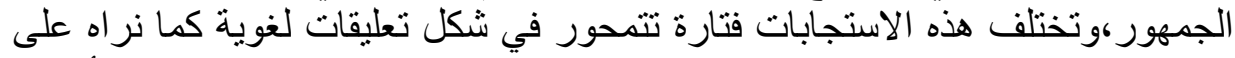

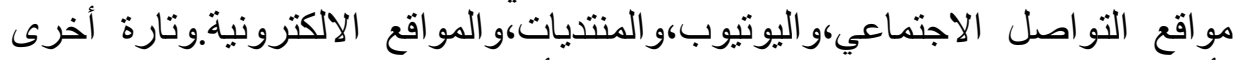

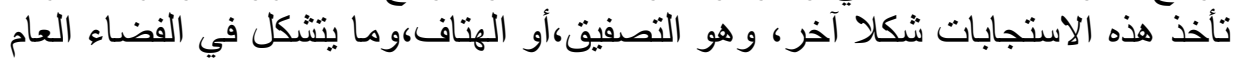
من تشكيلات رمزية.

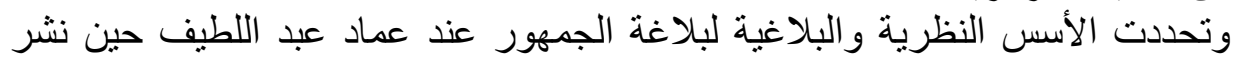

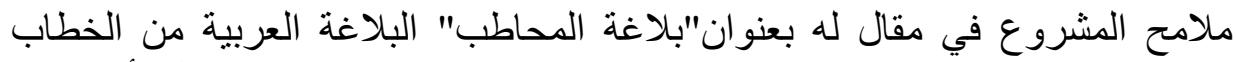

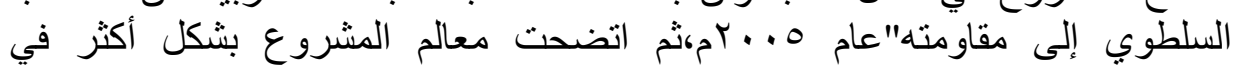

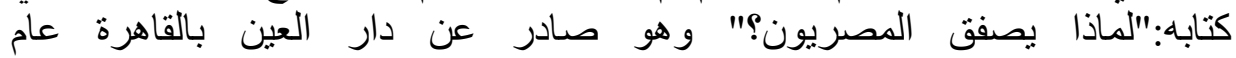

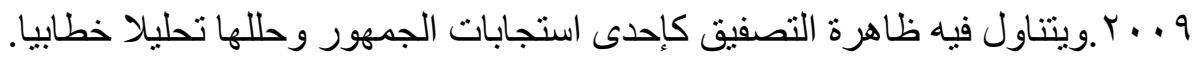

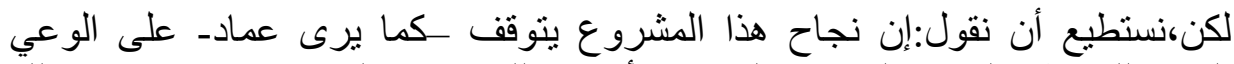

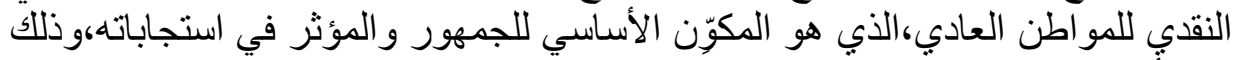

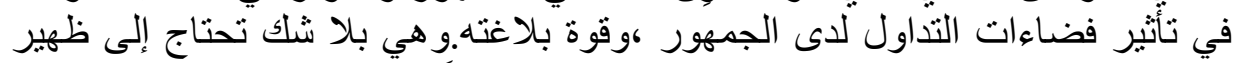

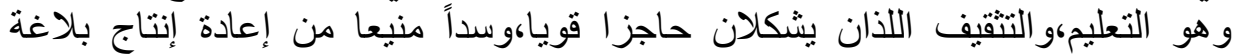

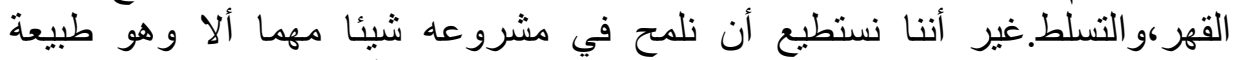

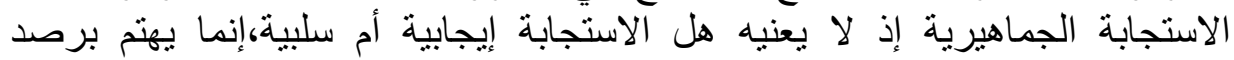

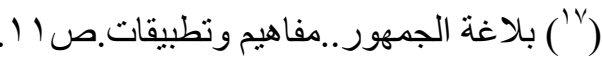


الاستجابة كرد فعل للحطاب،والعلاقات المغقدة التي يمكن أن تتشأ بين الخطاب و الاستجابة. العلاقة بين اللغة والإنسان في منهج عماد عبد اللطيف

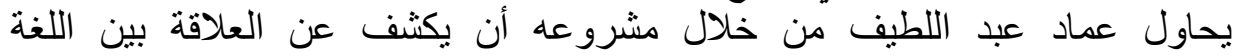

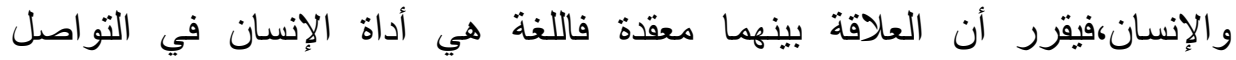

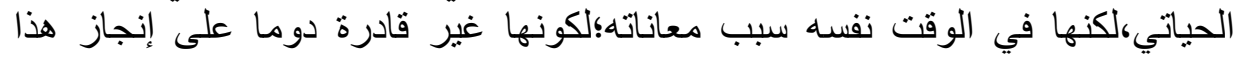

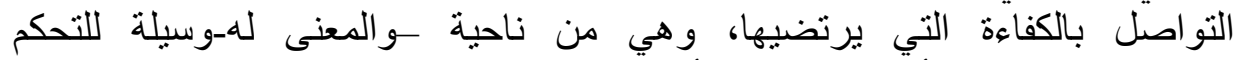
و السيطرة،يخضع بها أفراد وجماعات أفر ادا وجماعات من بات آخرين لسلطتهم،لكنها في المقابل

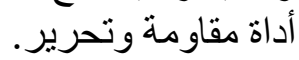
إن رأيه في ازدواجية اللغة رأيرة أنافذ عن بصيرة بدور اللغة وما يمكن أن تلعبه في دنيا

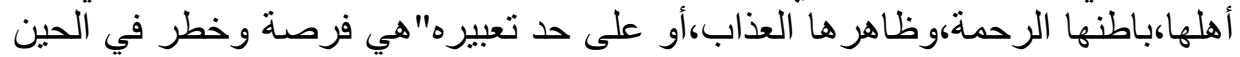

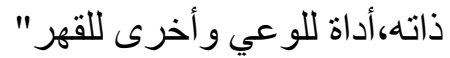

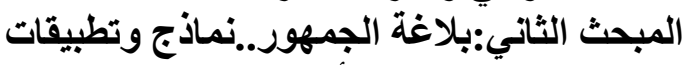

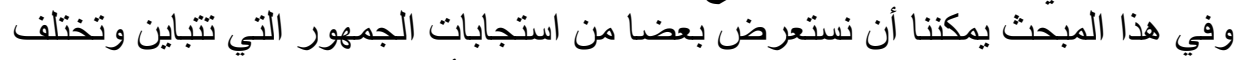

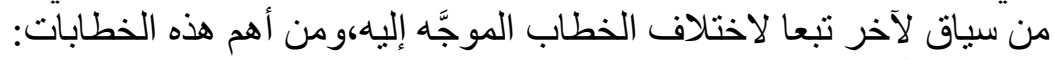

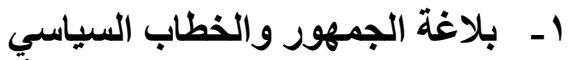

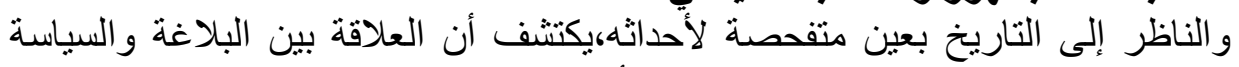

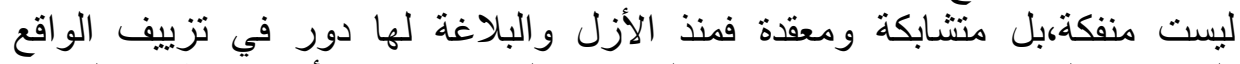

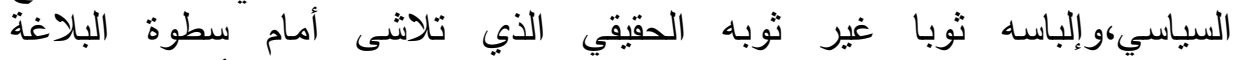

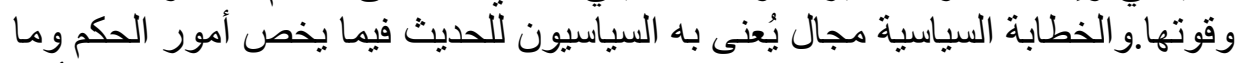

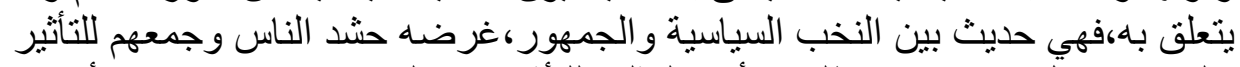

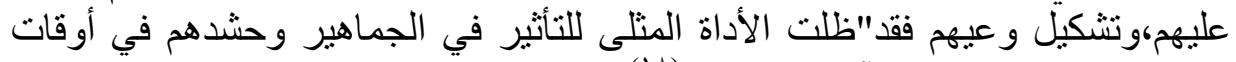

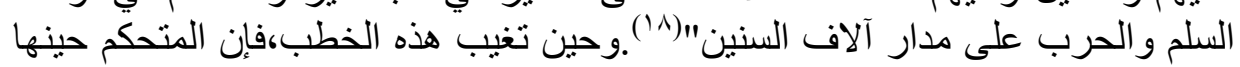

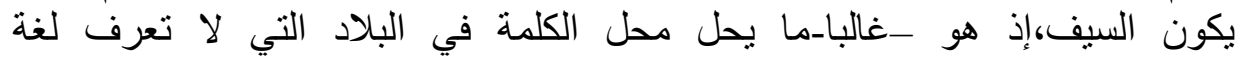

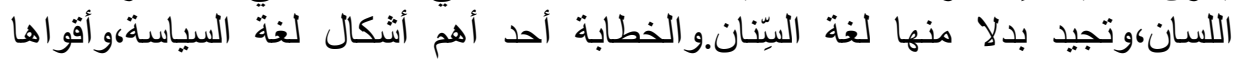

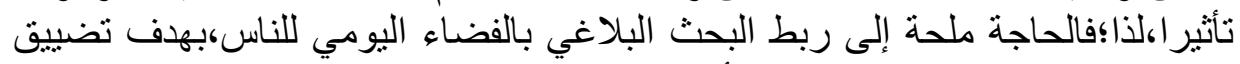

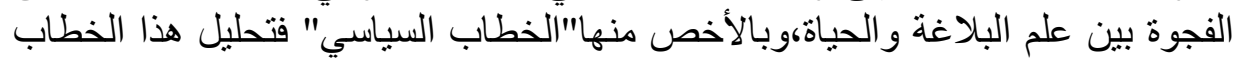

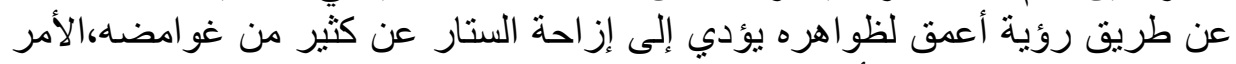

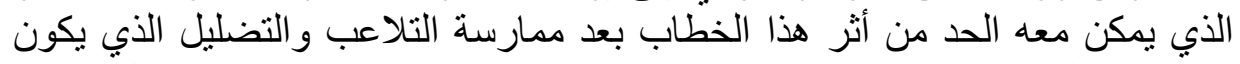

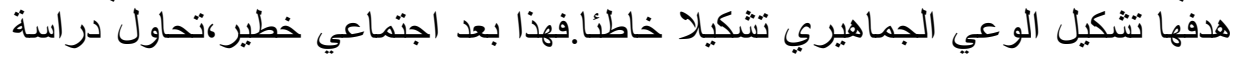

(1) (1) عماد عبد اللطيف،الخطابة السياسية في العصر الحديث.ص IV 


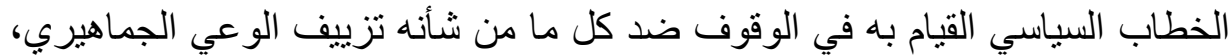

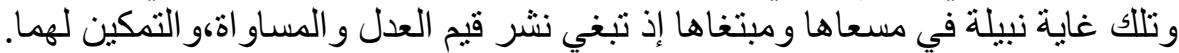

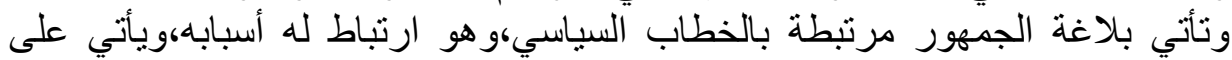

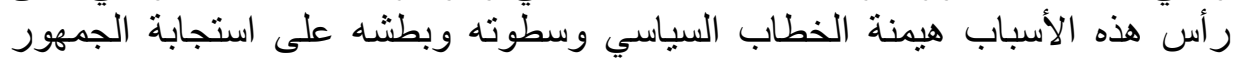

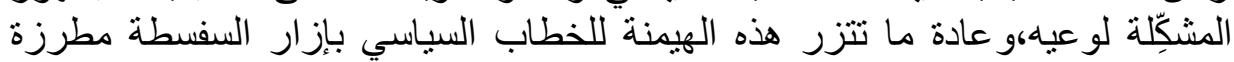

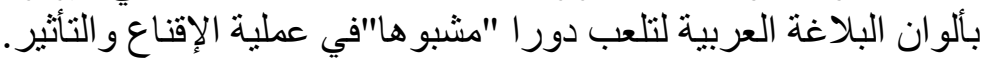

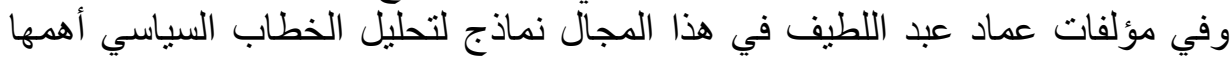

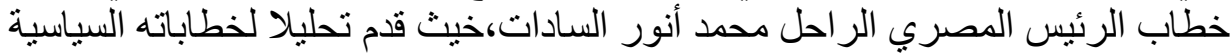

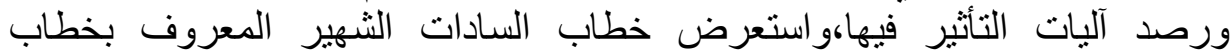

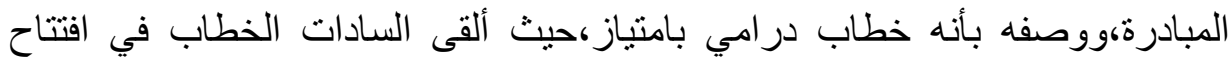

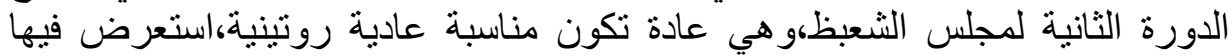

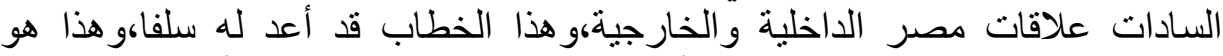

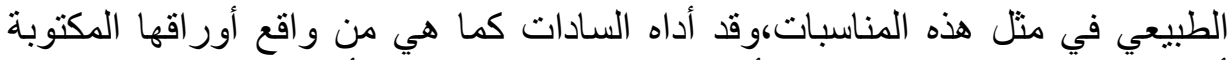

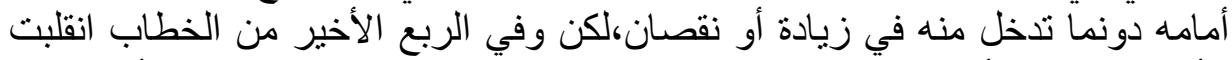

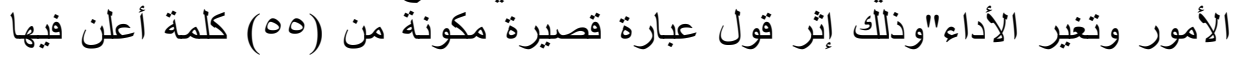

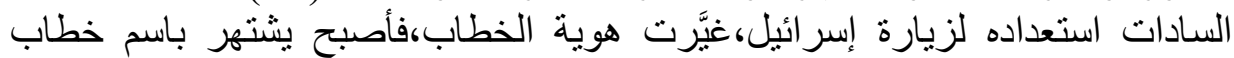

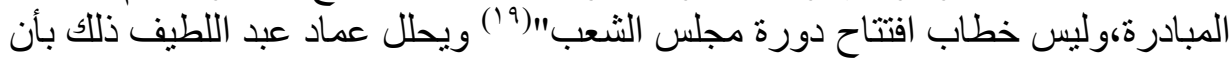

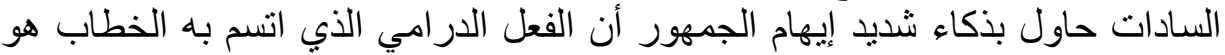

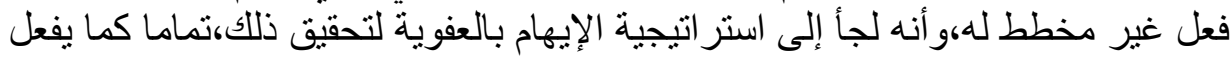

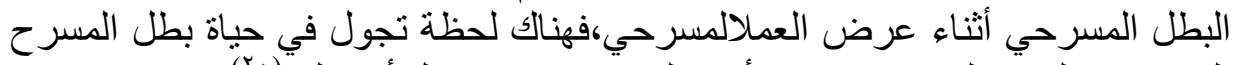

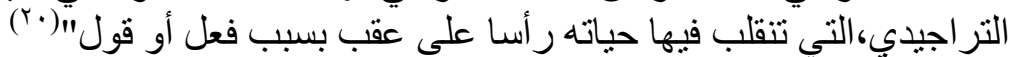

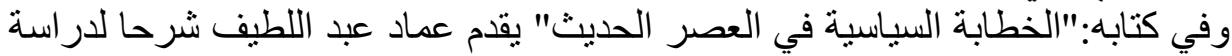

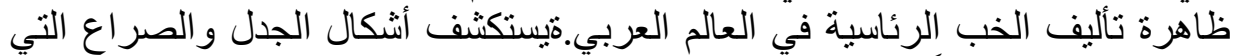

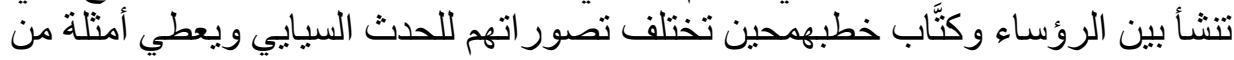

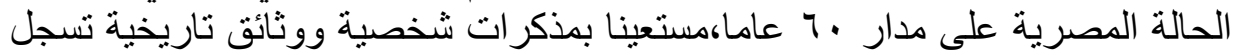

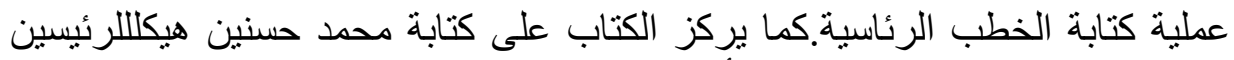

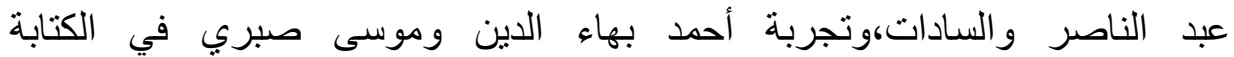

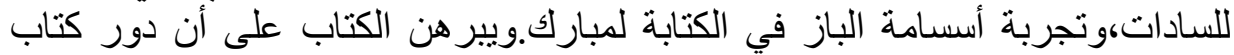

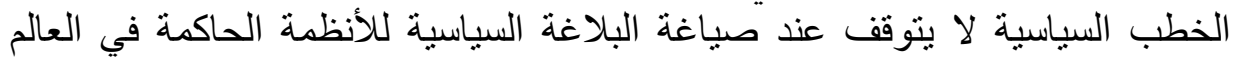

(99 (19) عماد عبد اللطيف، مقال خطابات السادات من البرلمان إلى الكينست، بوابة صحيفة الوطن

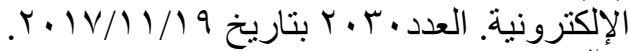




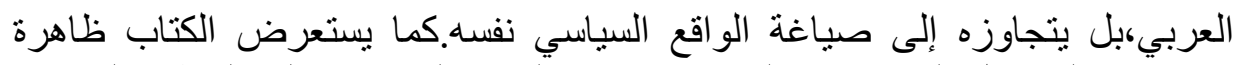

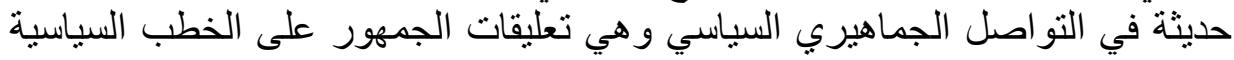

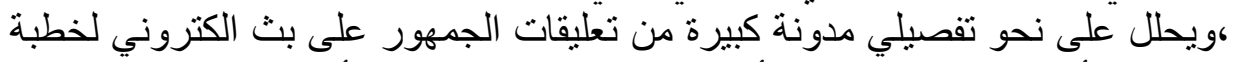

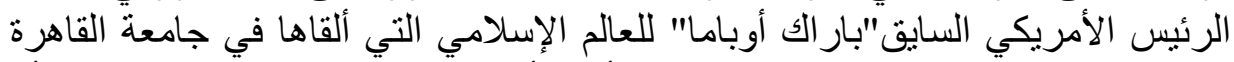

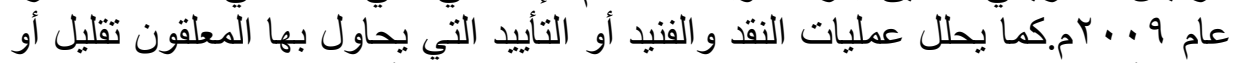

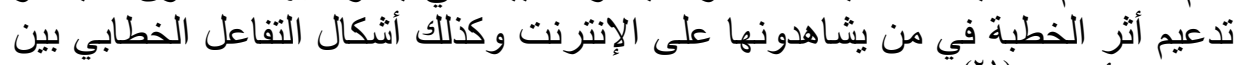

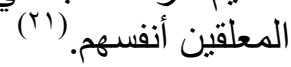
وفي مقاله المنشور بصحيفة القدس العربي بعنوان"حين تقارع البلاغة السياسة" يقدم

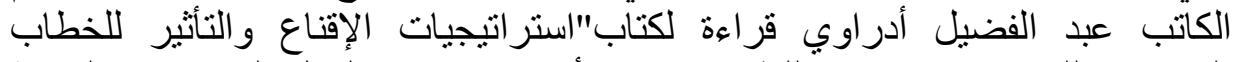

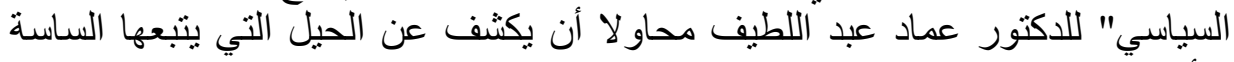

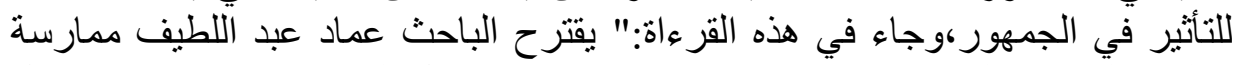

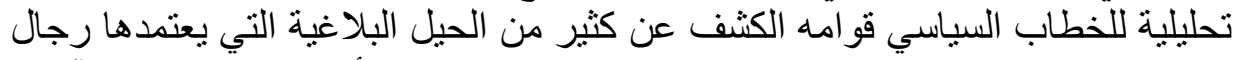

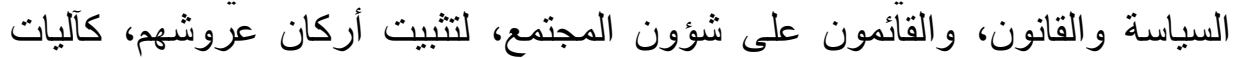

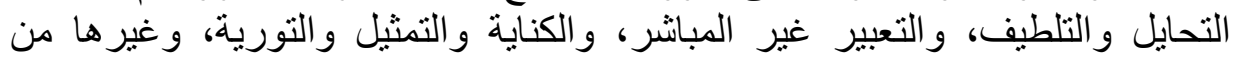

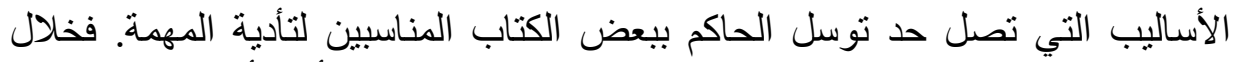

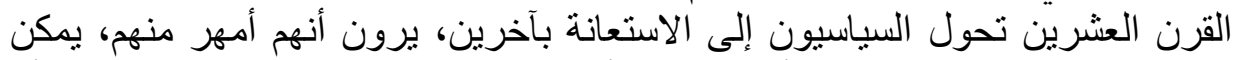

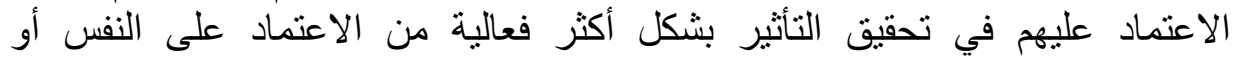

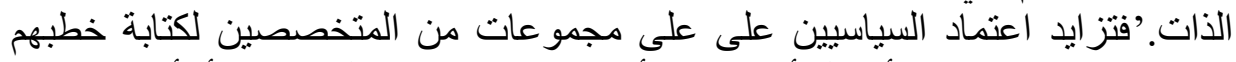

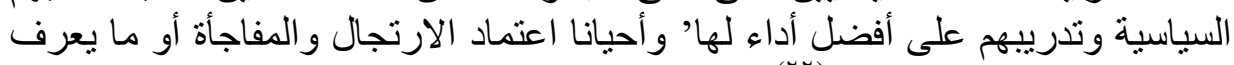

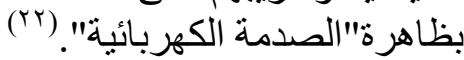
لقد حاول عبد اللطيف من خلال هذا الكتاب، وكتاب "الخطابة السياسية في العصر

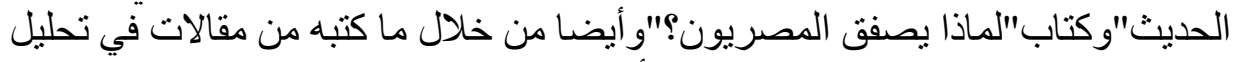

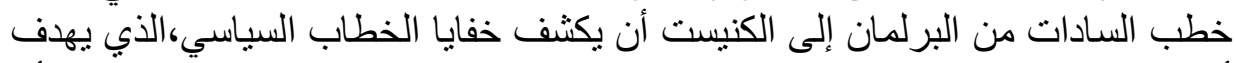

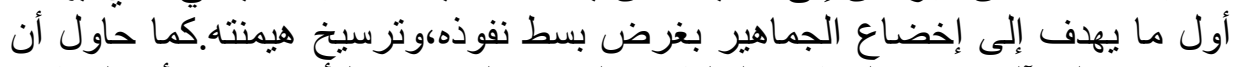

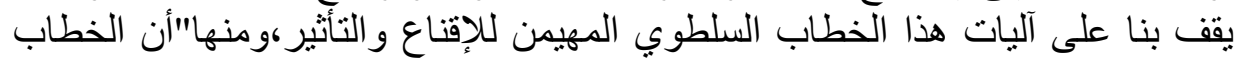

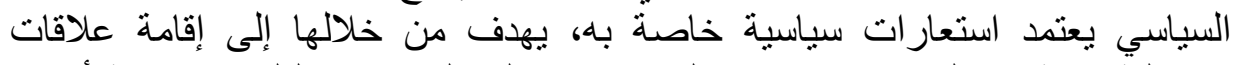
تواصلية خفية مع الجمهور، ويينغي النفاذ عبر ها إلى الششاعر والقلوب، و إقامة أجواء

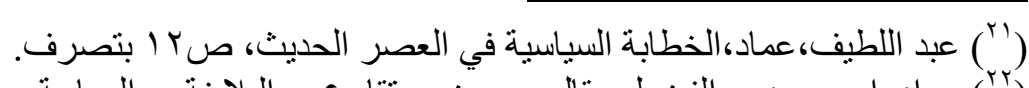

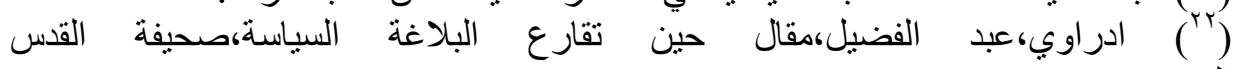


من الحميمية والإيجابية تجاه الآخرين، وربما النيل من بعض الخصوم وتحطيم

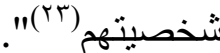

ويثنير عبد الفضيل أدارواي إلى أن عماد عبد اللطيف طبق ذلك المنحى على خطابات

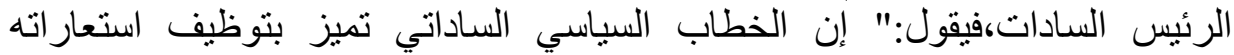

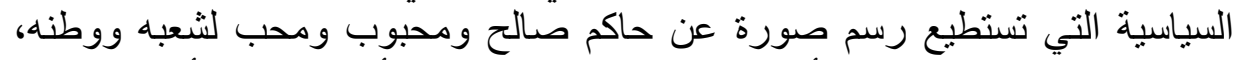

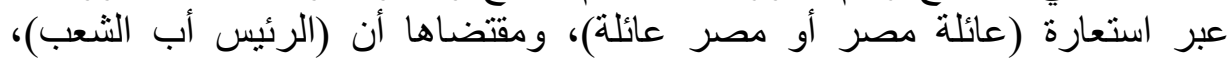

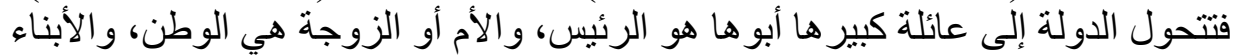

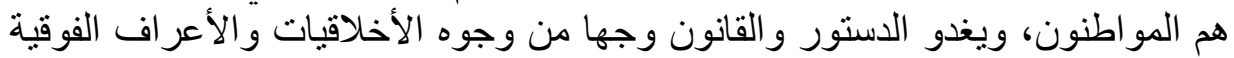

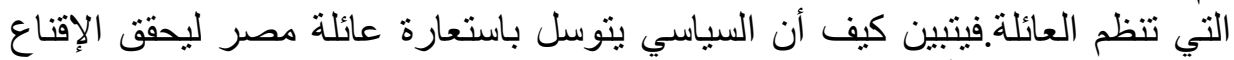

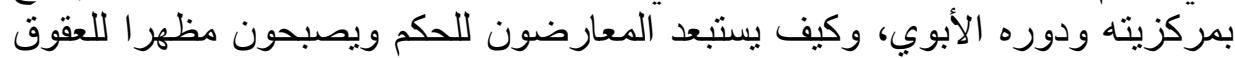
إن هم خرجوا عن طاعة الأب.وكيف أن مخالفة الأبة القانون تصبح خروجا عن الأخلاق و والأعر اف المسلم بها. ونخلص من ذلك الر أي إلى أن الحاكم يعتمد على أن يتناصَّ خطابه السياسي مع النصِّ

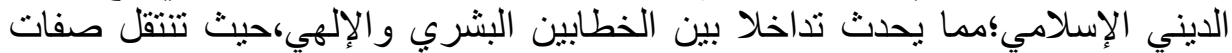

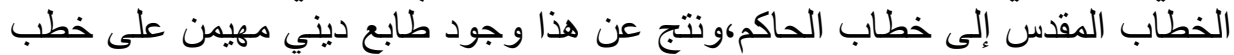

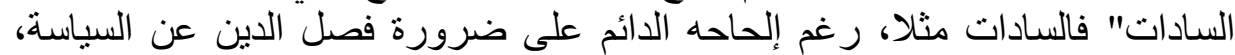

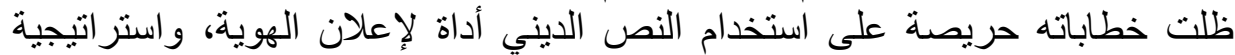

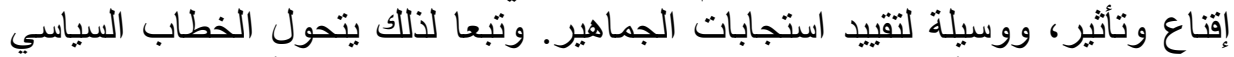
بسبب استغلاله الرأسمال الرمزي للاين، إلى خطاب ممتلكا قدرة أكبر على السيطرة

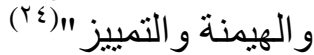
ولعل من أشكال استغلال الطاقة الرمزية للدين في السياسة، تحويل اسم (أنور السادات)

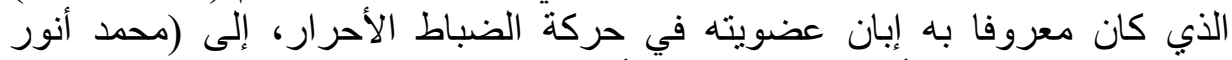

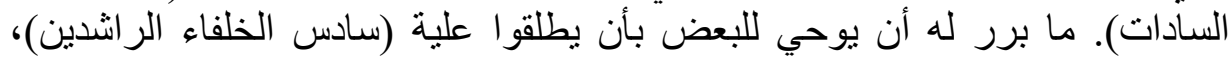

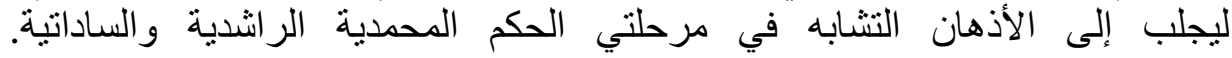

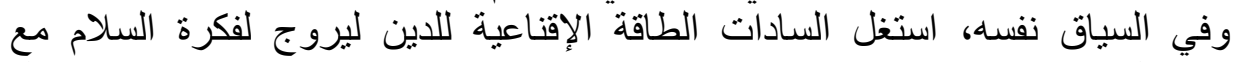

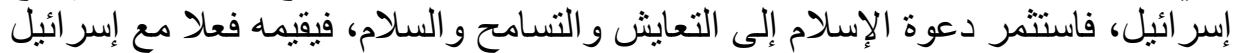

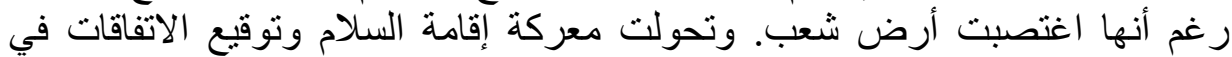

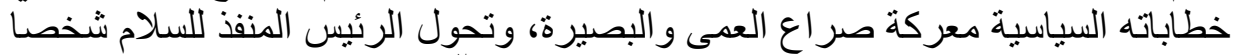

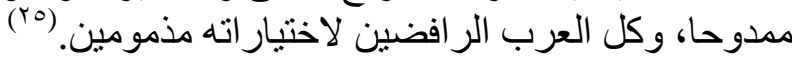




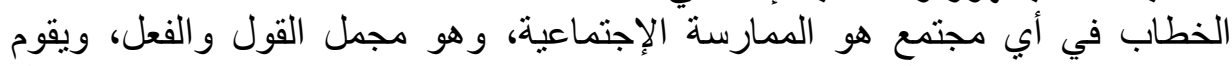

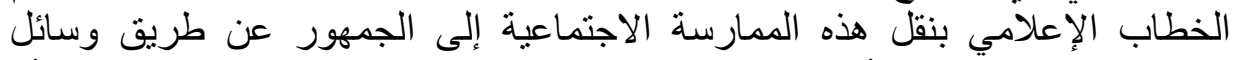

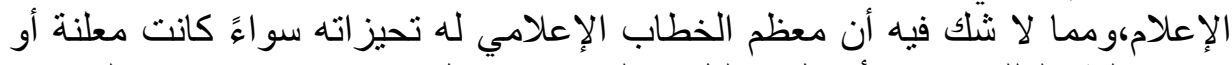

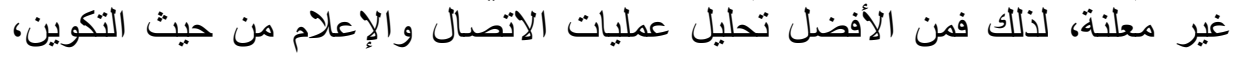

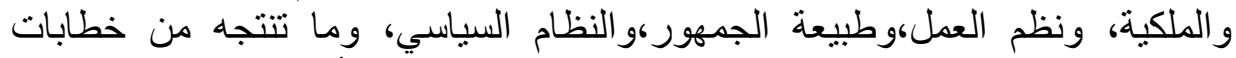

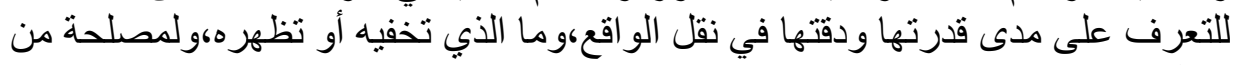
تعمل، وما هي استر اتيجياتها.

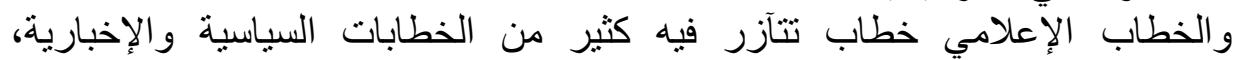

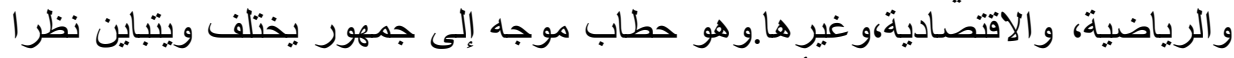

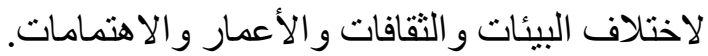

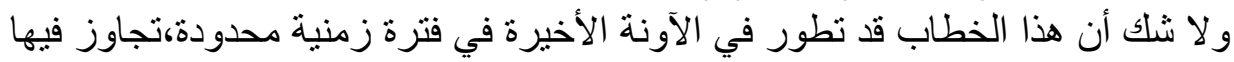

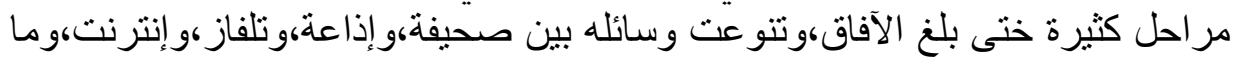

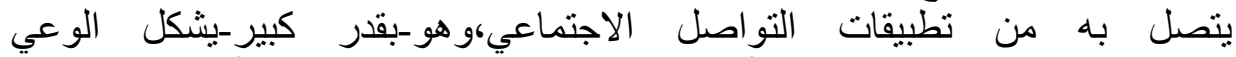

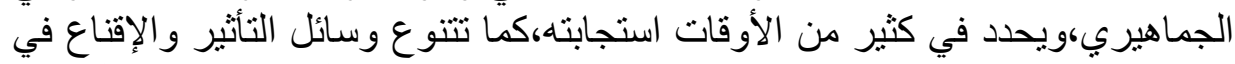

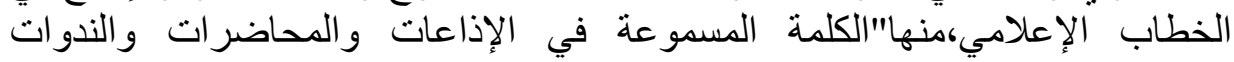

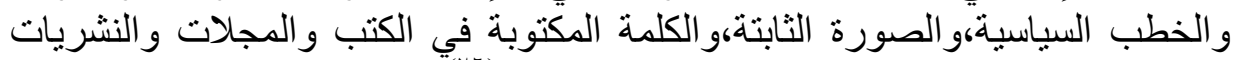

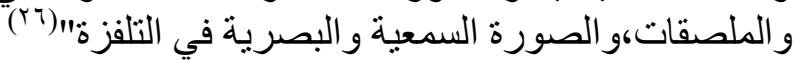

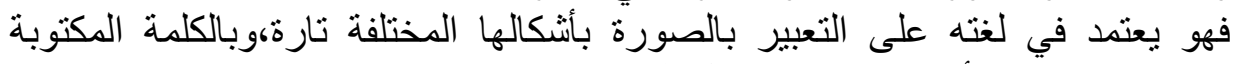

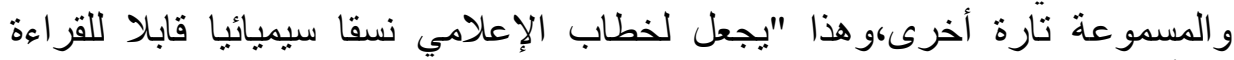

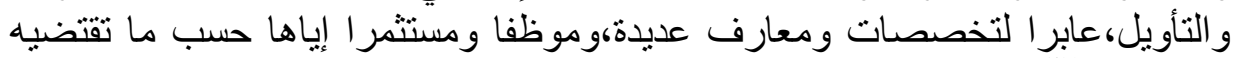

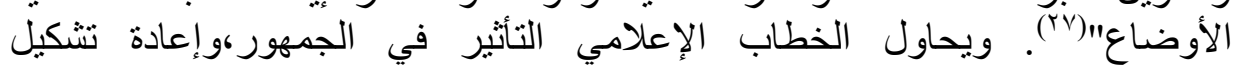

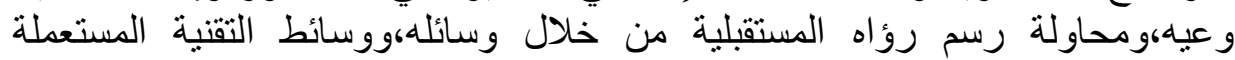

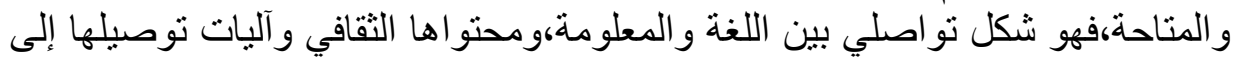

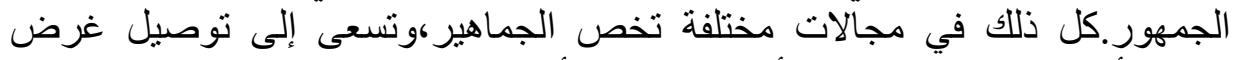

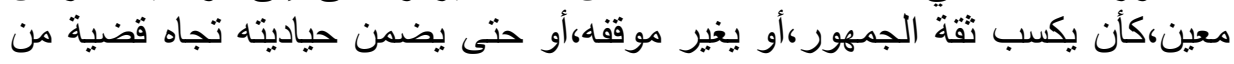
القضايا.

(ج)بثير إيرير ،التحليل السيميائي للخطاب الإشهاري،در اسة في تفاعل أنظمة العلامات وبلاغة

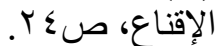

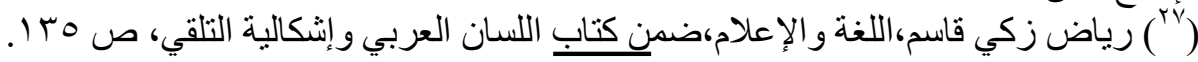


ومن أجل ذلك" أصبجت وسائل الإعلام،أو التواصل الجماهيري نوظف بلاغة الإقناع

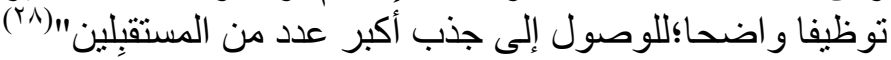

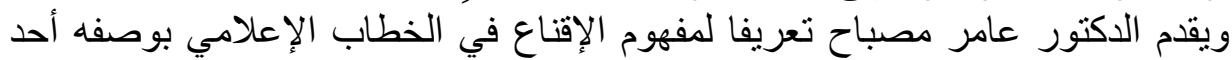

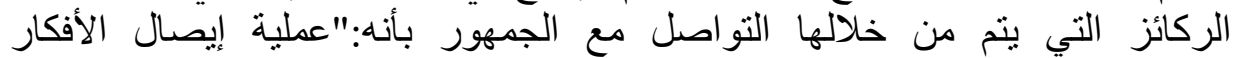

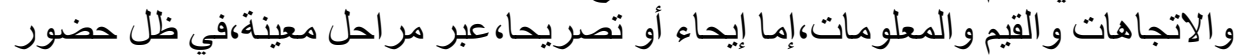

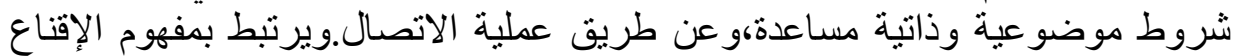

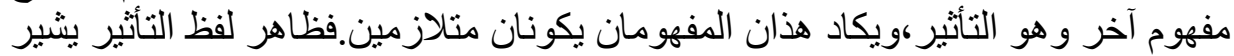

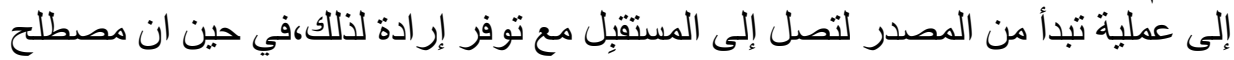

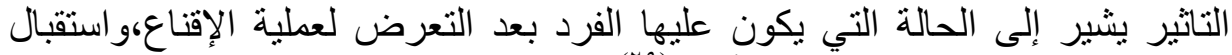

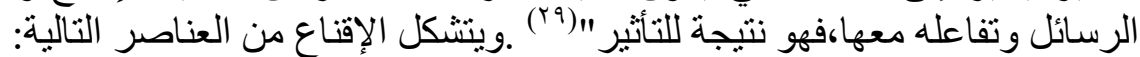

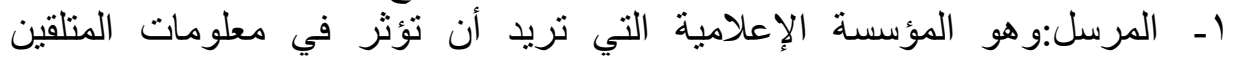

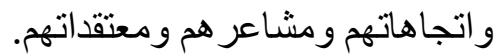

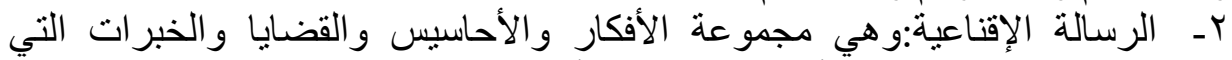

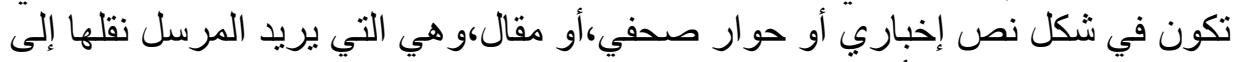
المتلقي لإقناعه بها،و التأثنير عليه طبقاري ألها.

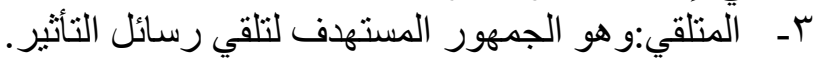
ع- الوسيط:و هو الوسيلة الإقناعية الناقلة للإسالة الإقناعية.

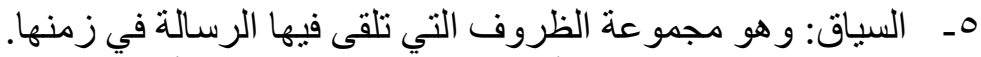

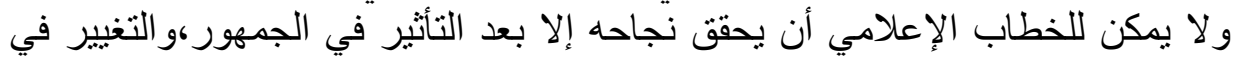

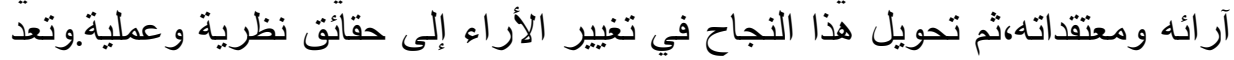

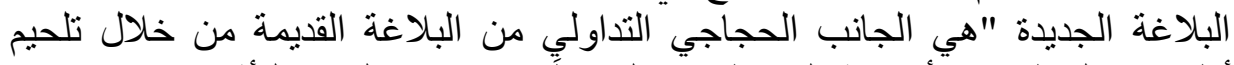

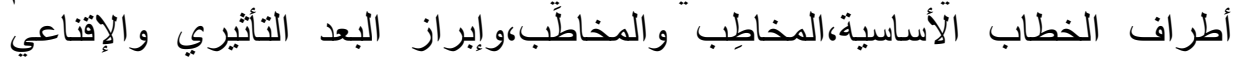

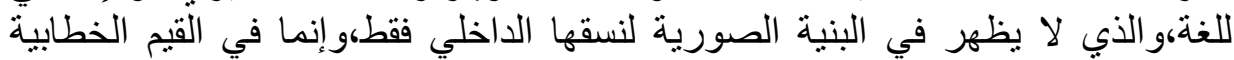

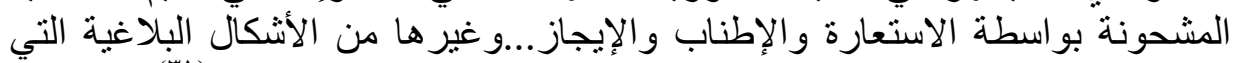

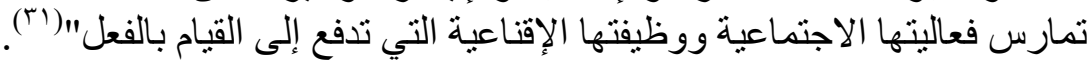

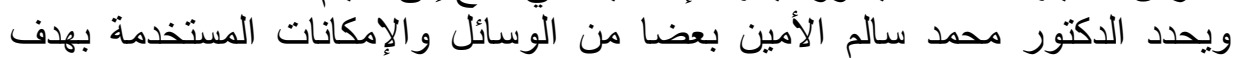
الوصول إلى المخاطب،والتأثير فيه"ومن تللك الوسائل ما هو الأنات فكري كالحجة

(المعمد سالم الأمين الطلبة، الجِجاج في البلاغة المعاصرة، بحث في بلاغة النقا

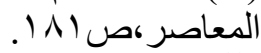

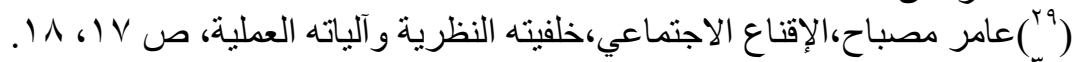

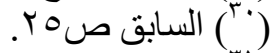

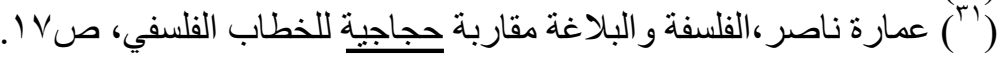




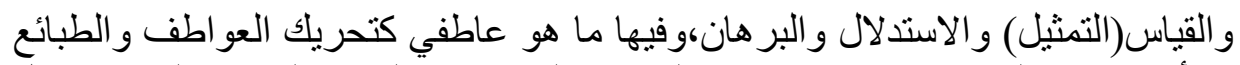

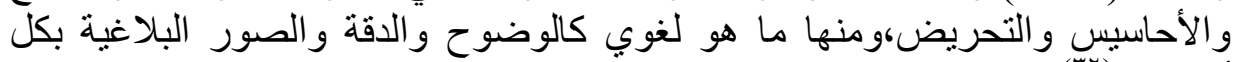

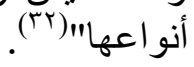

و الخطاب الإعلامي في مجمله حطاب إقناعي إبلاغي يهدف إلى التأثير في الجمهور كما

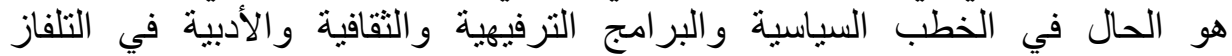

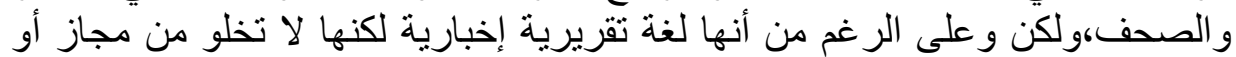

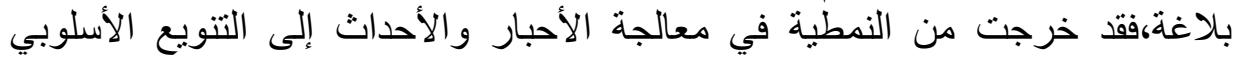

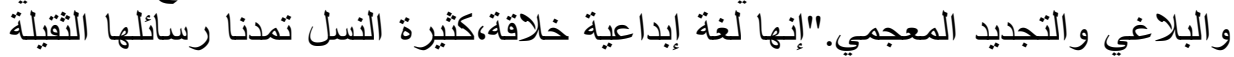

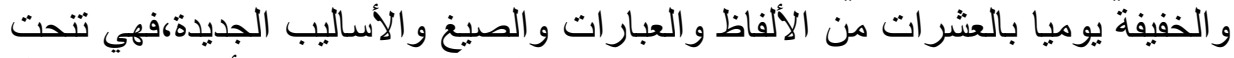

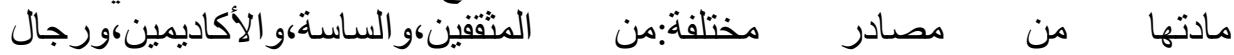

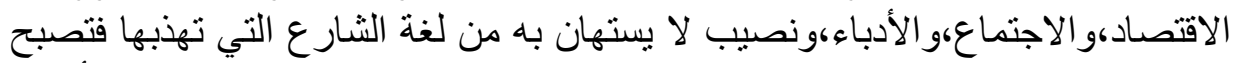

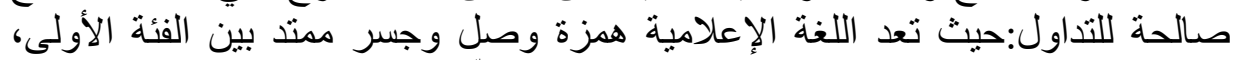

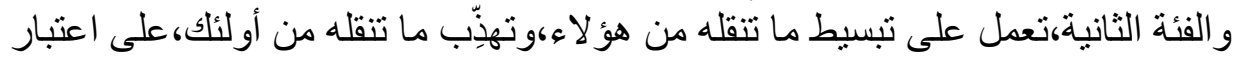

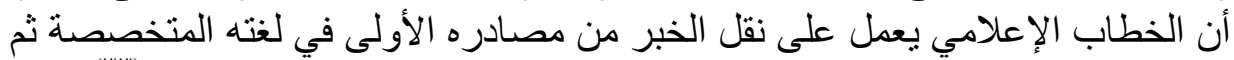

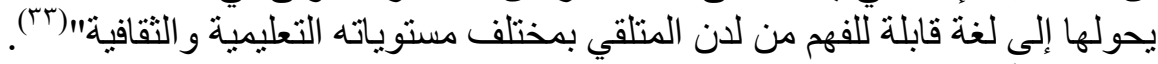
وسائل التأثير في قناعات الجئ الجماهير

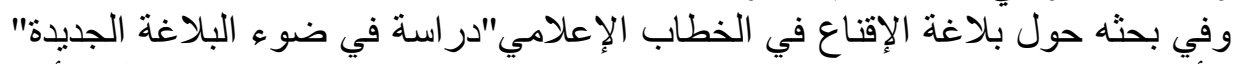

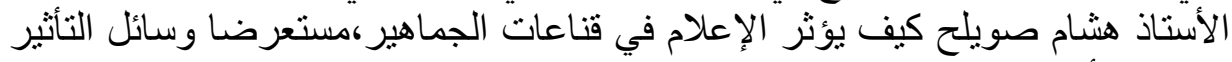
المنطوقة أو لا،ومنها:

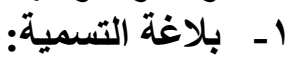

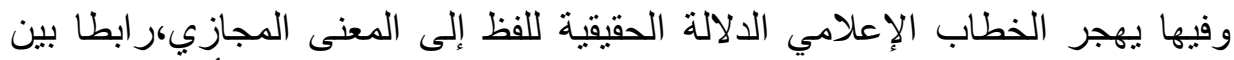

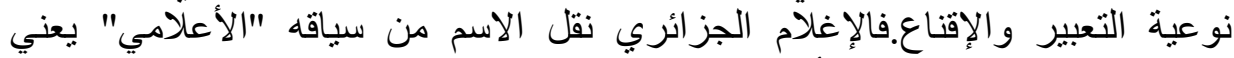

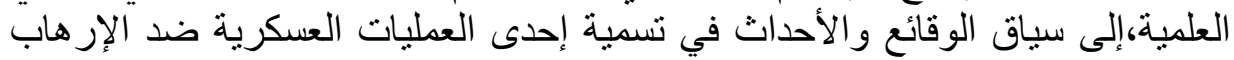

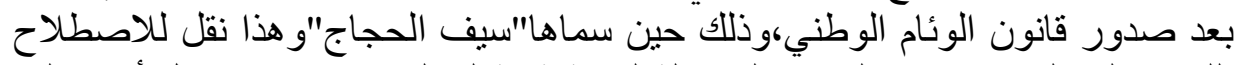

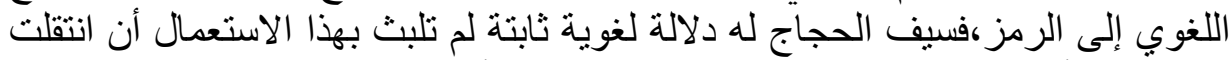

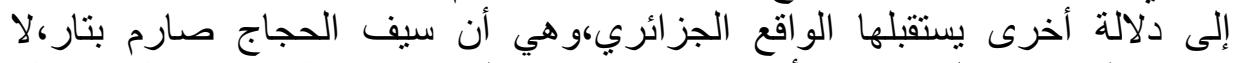

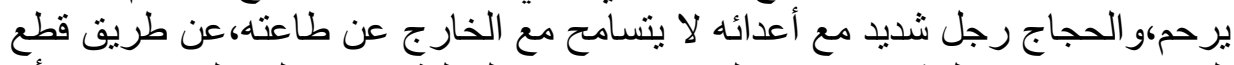

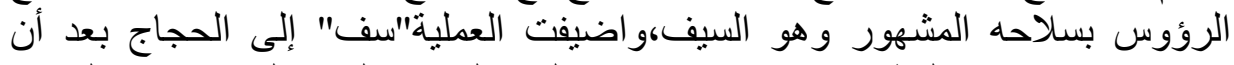
استعارت منه سيفه لقطع رؤوس الإرهابيين الذين لم يستسلموا،ولم يخضعوا لقانون الفئن

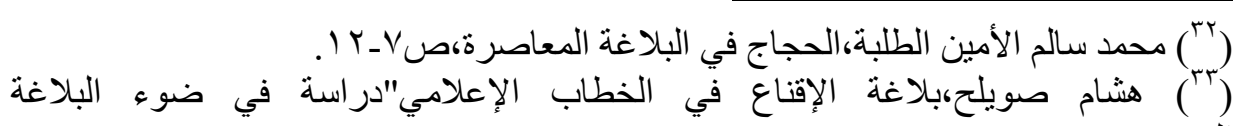


الوئام المدني،وبهذا انتقلت التسمية من معناها اللغوي الأول، إلى معناها الدلالي الو اقعي التي

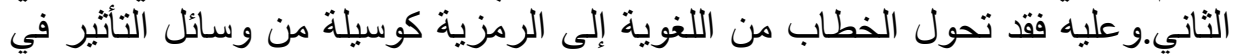

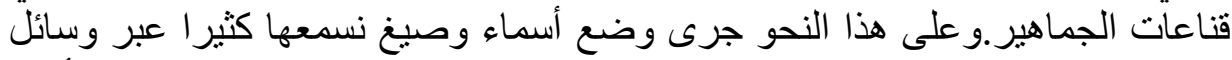

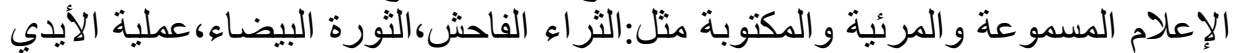

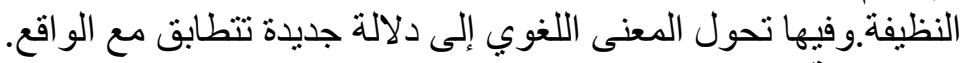

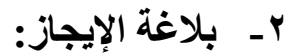

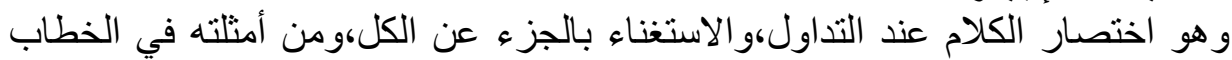

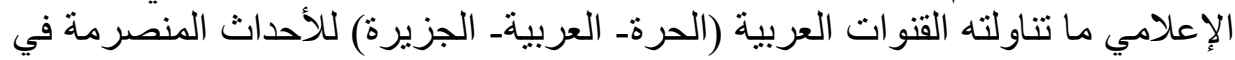

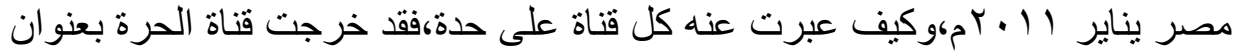

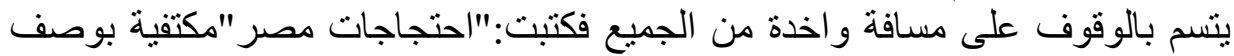

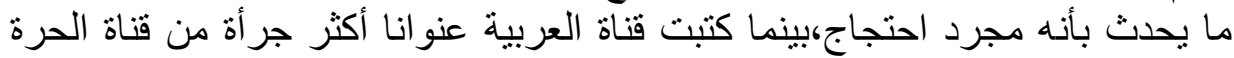

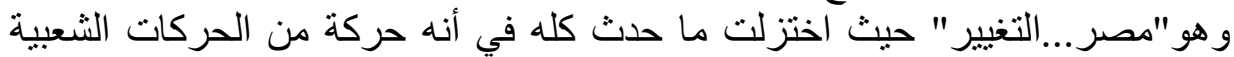

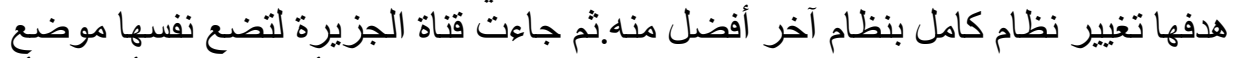

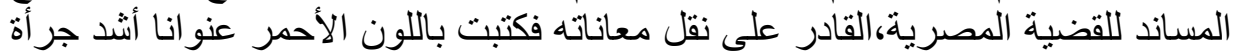

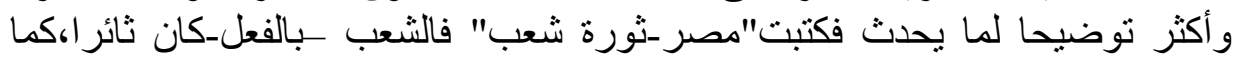

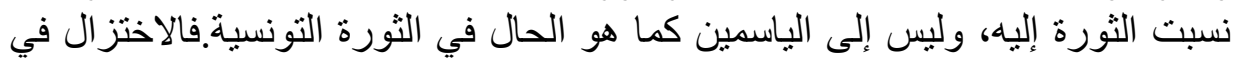

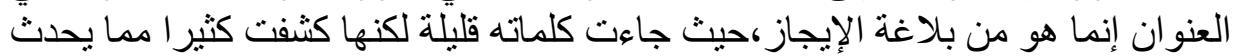

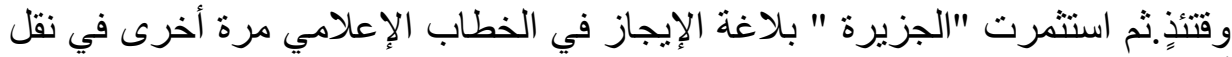

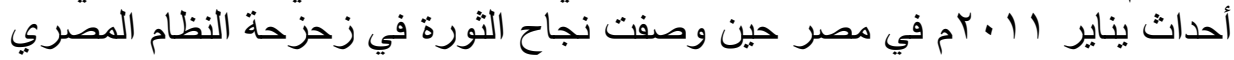

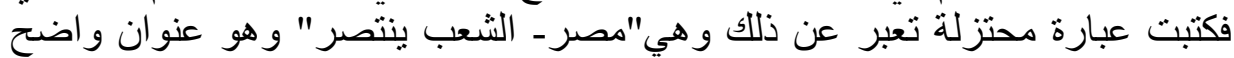

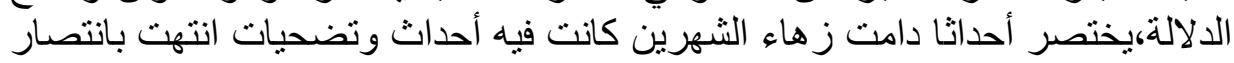

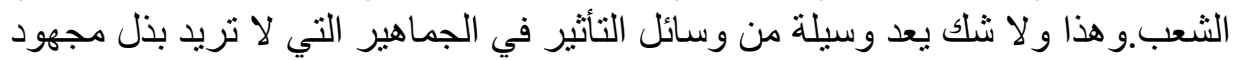

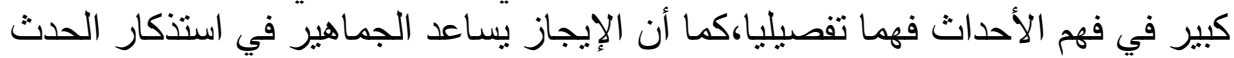

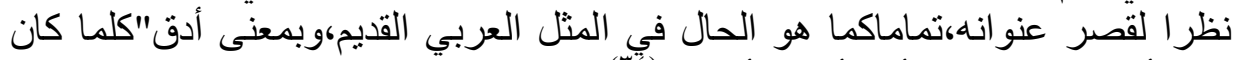

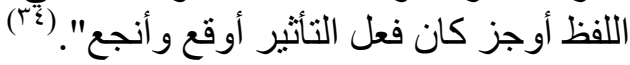
بـ المجاز: يقول عبد السلام المسدي في كتابه"السياسة وسلطة اللغة"متحدثا عن المجاز في التعبير

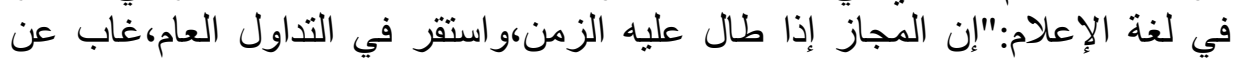

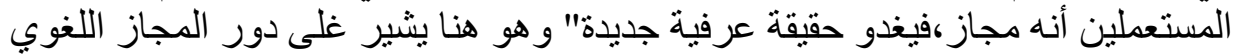

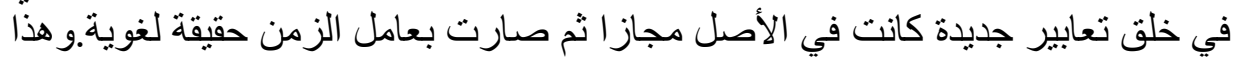

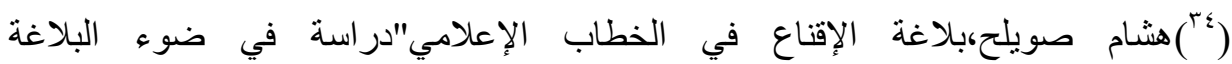

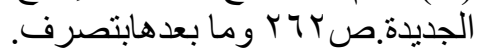


النوع من المجاز شائع في لغة الإعلام يستخدمه وسيلة من وسائل التأثثر في

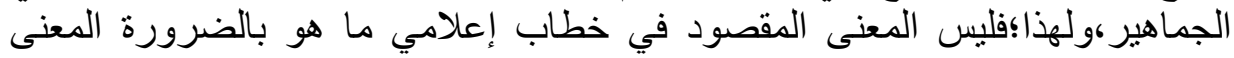

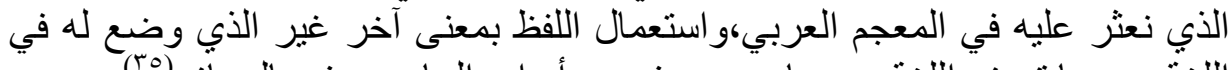

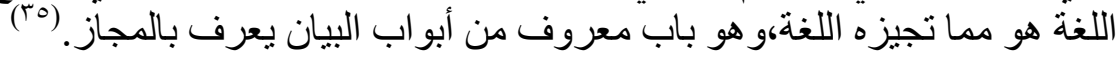

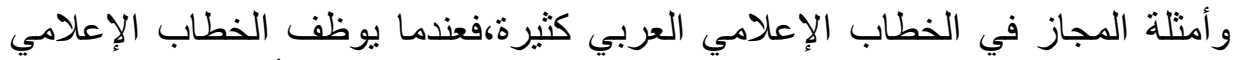

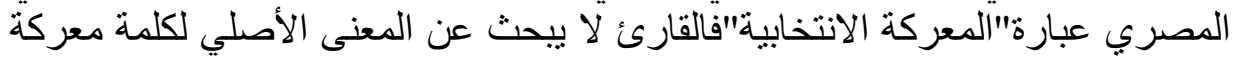

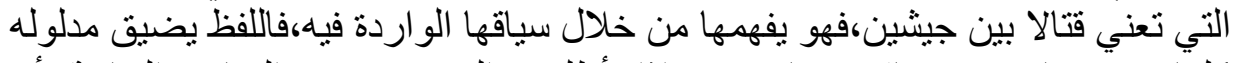

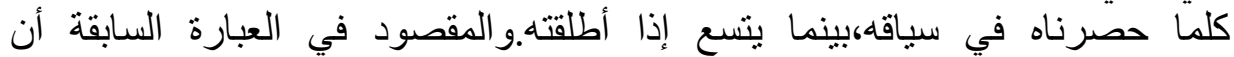

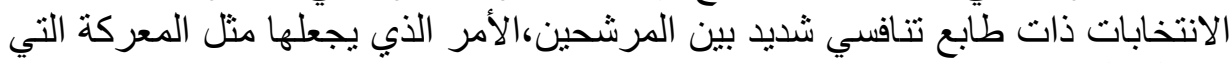

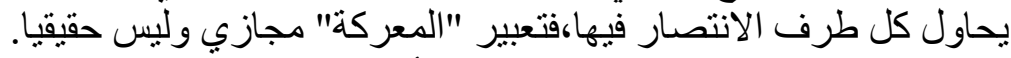

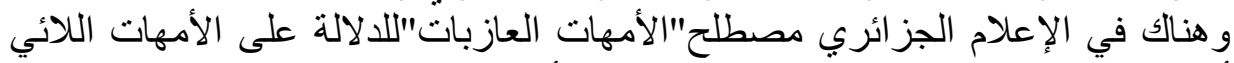

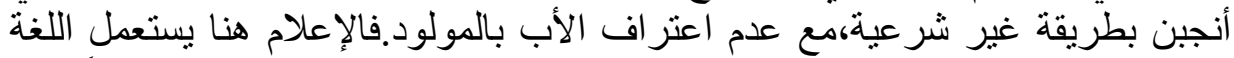

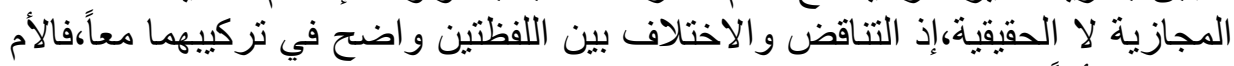

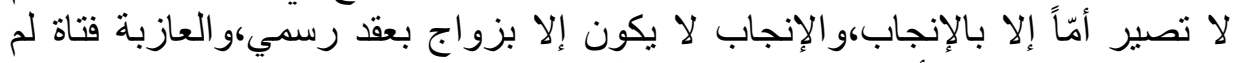

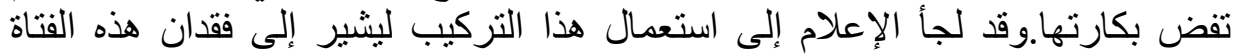

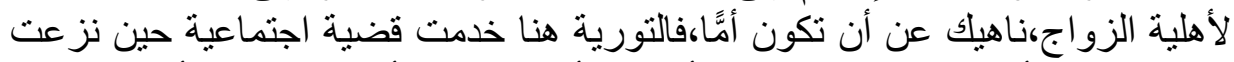

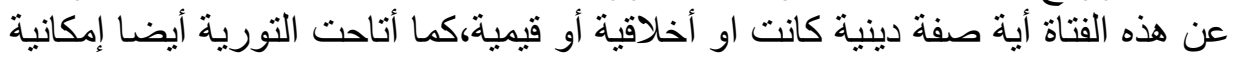

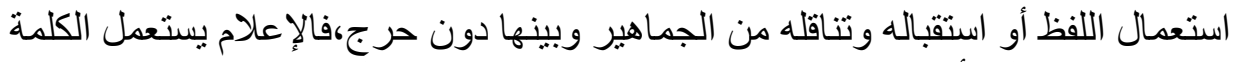

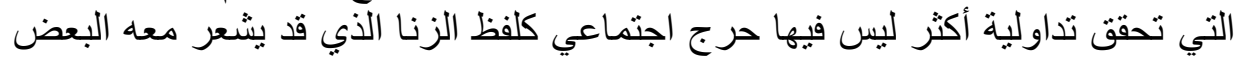

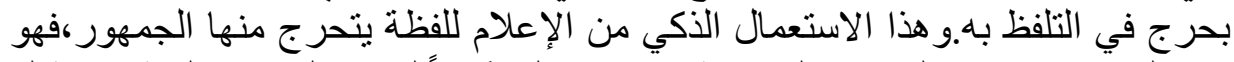

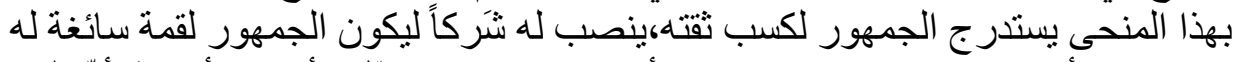

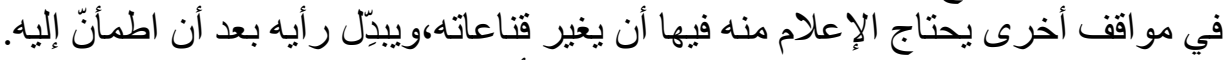

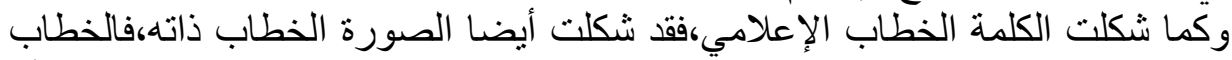

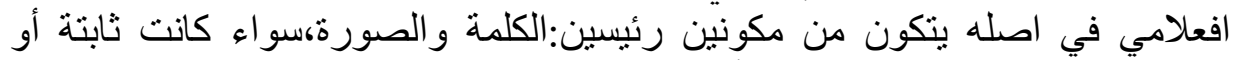

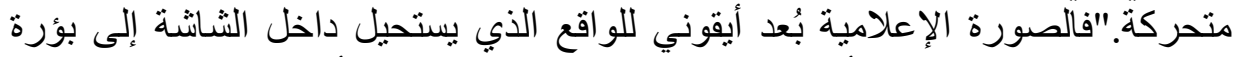

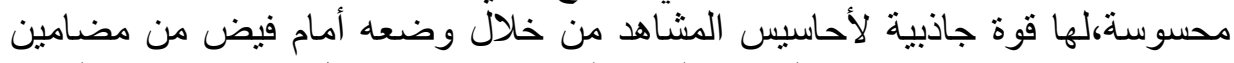

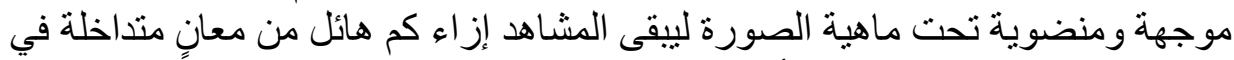

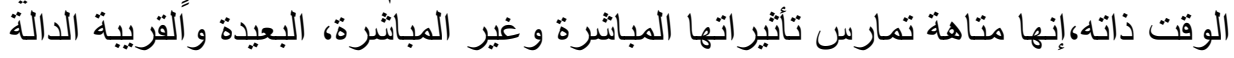

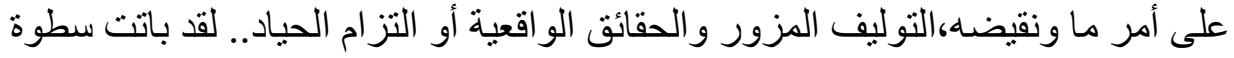

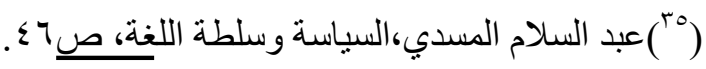
1.0 
الصورة إعلاميَّا تحمل الثيء ونقيضه؛ فنسق الهيمنة يستبطن في داخله نسق آخر

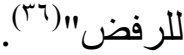

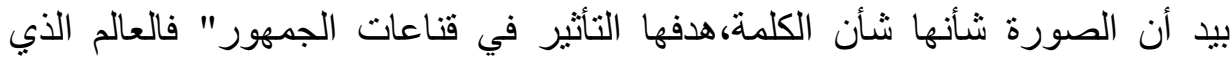

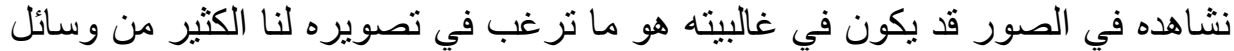

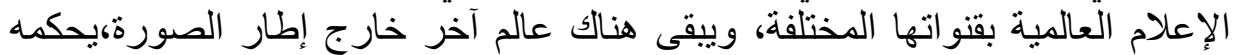

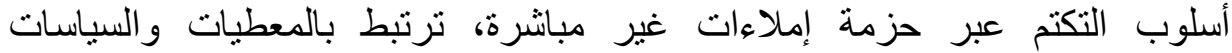

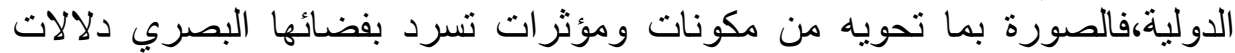

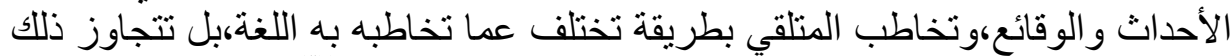

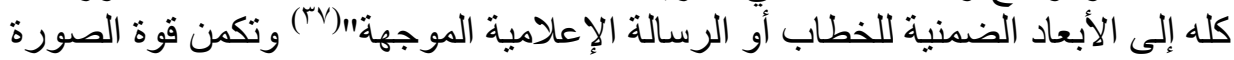

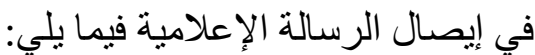

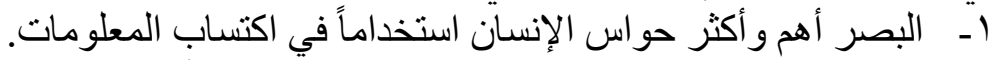

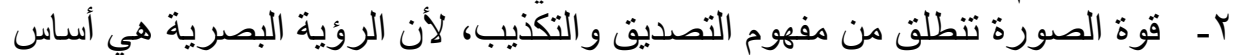

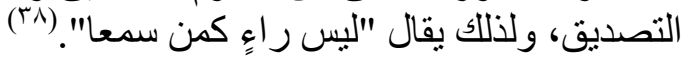

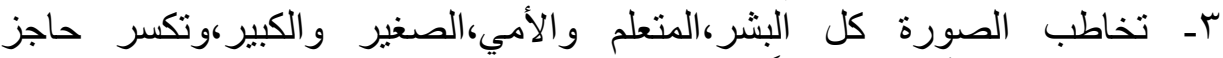
اللغات،لذلك فهي الأوسع انتشار اً.

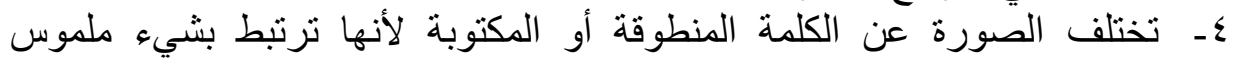

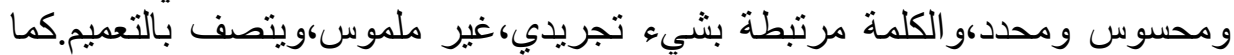

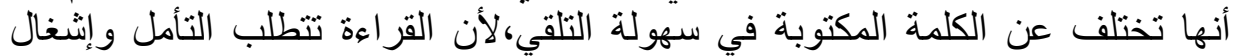
الذهن، أما الصورة فلا تحتاج جهداً ذَّنياً كبير اً لتلقيها.

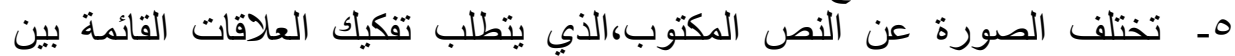

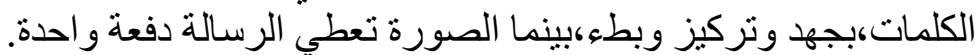

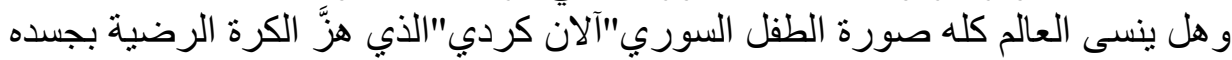

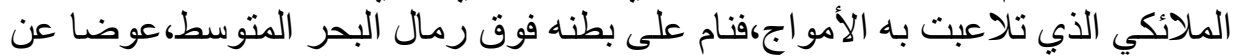

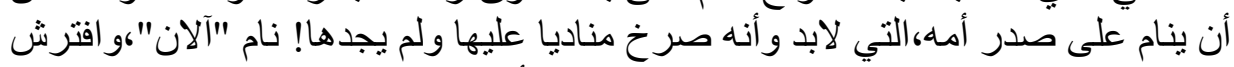

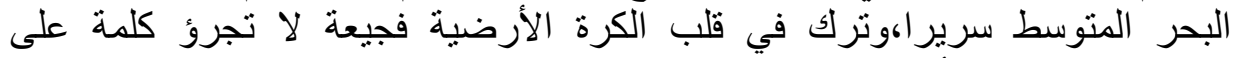

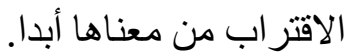

(r) السابق.

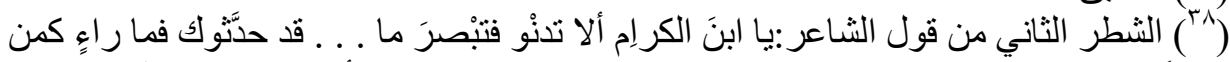

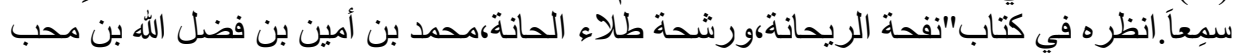




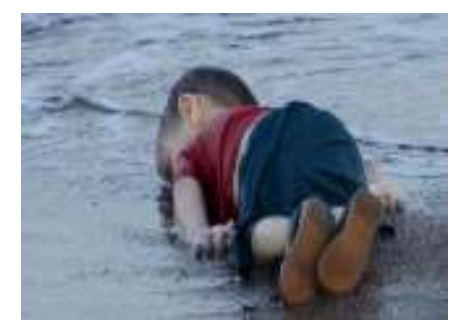

و لا شك أن هذه الصورة كان لها الوقع الأليم عالمياهوتعاطف معها المجتمع المدني

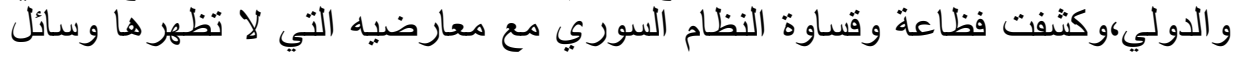
الإعلام المجلية و الدولية.

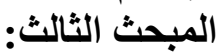

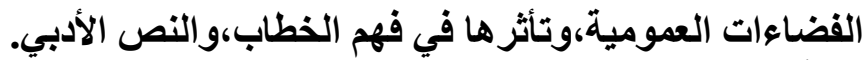

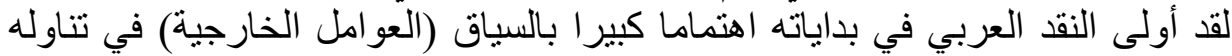

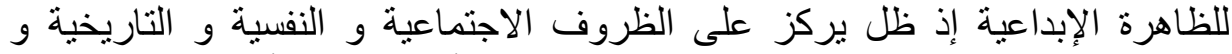

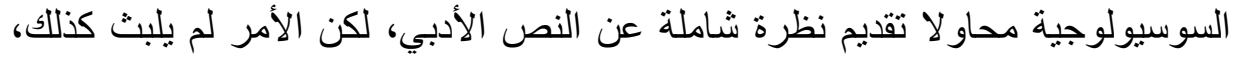

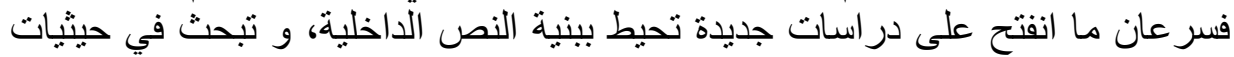

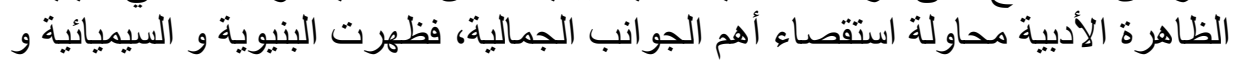

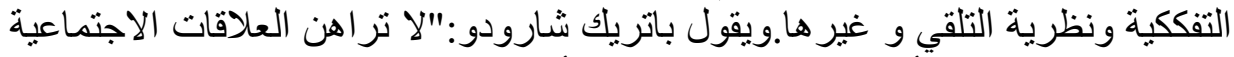

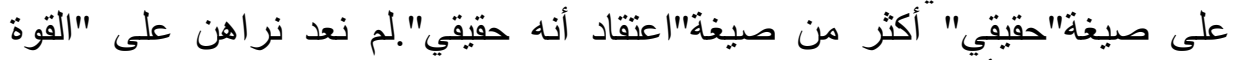

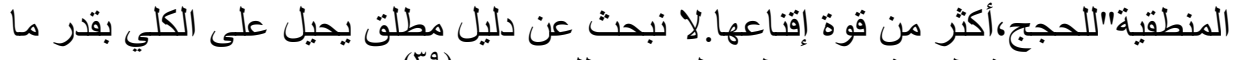

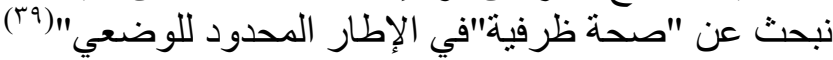

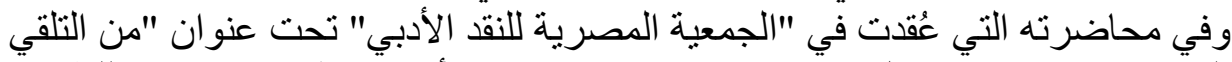

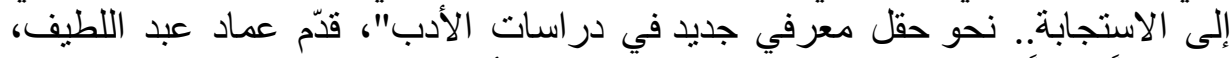

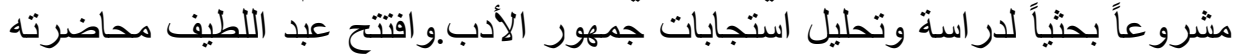

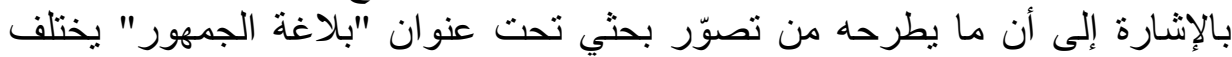

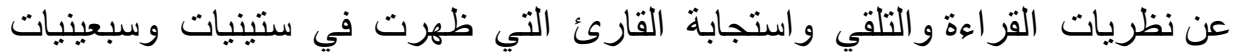

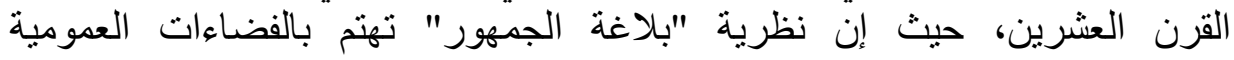

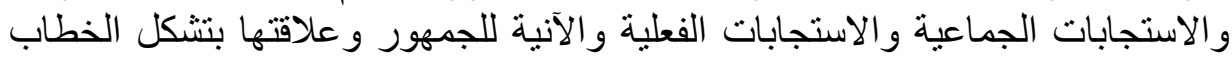

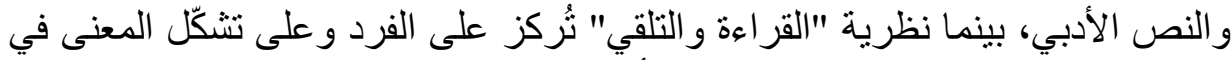

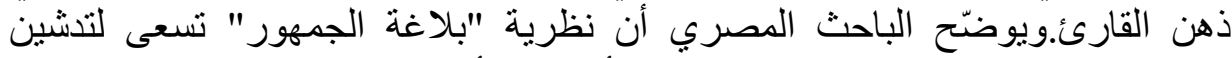
ممارسات بلاغية مغايرة لنلاك المستقرة منذ أكثر من ألفية ونصف، عبر الدية الانتقال بمجال

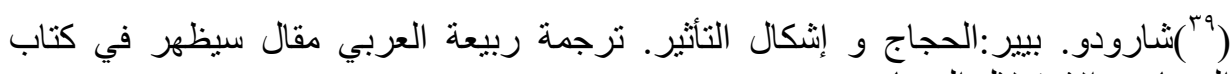
$\overline{1 \cdot V}$ الحجاج و الاستدلال الحجاجي. 
اهتمام البلاغة من المتكلّم إلى المخاطَب، بحيث تضع في بؤرة اهتمامها الاستجابات

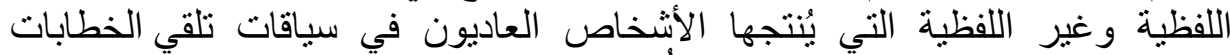

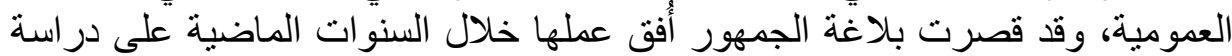
استجابات الجمهور أثناء تلقي نصوص التهات الحياة اليومية، وخطاباتها.

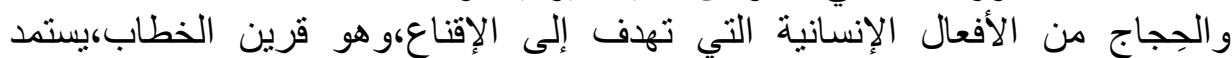

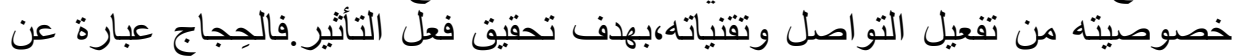

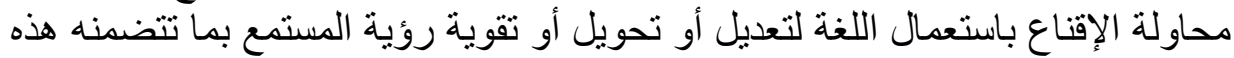

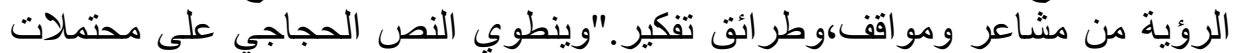

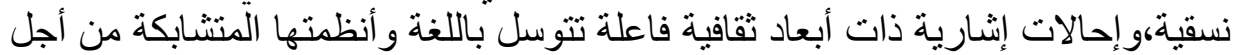

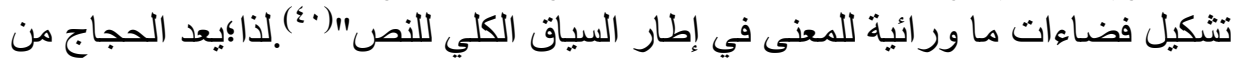

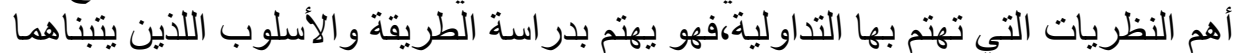

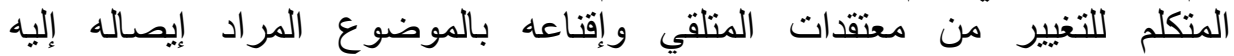

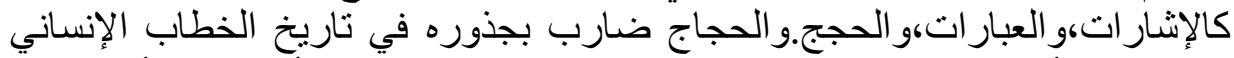

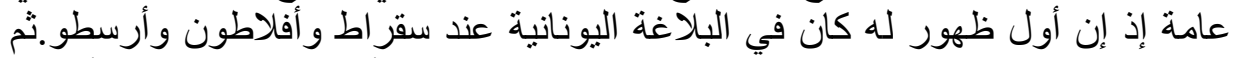

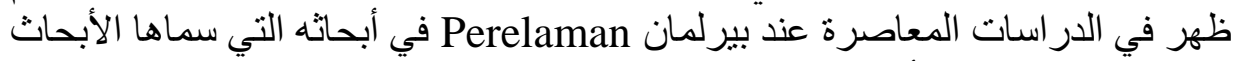
الجديدة؛نظر الحداثة الأبعاد التي تهنم بهاه التها.

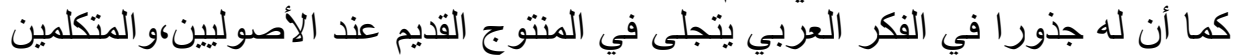

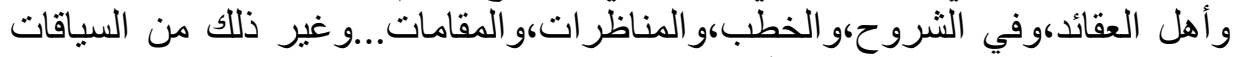

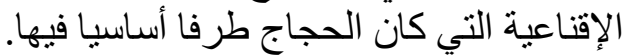

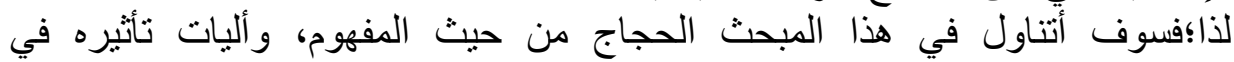

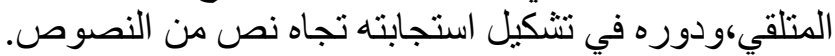

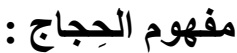

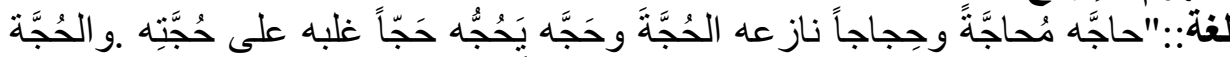

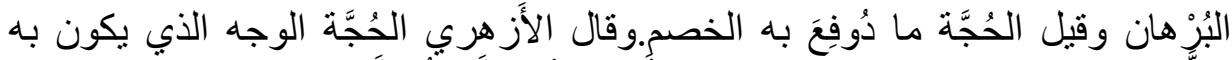

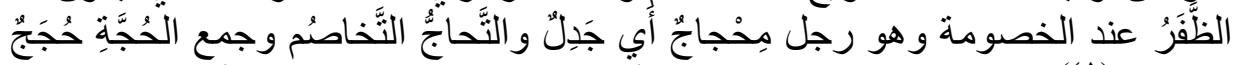

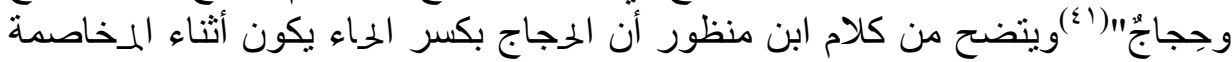

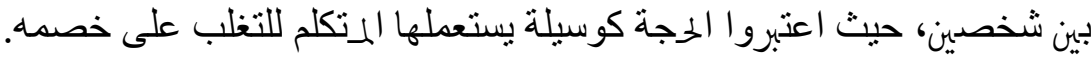

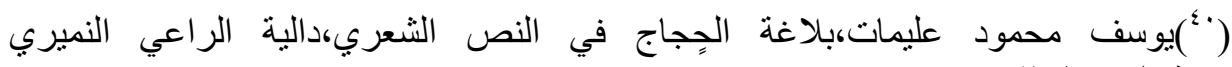

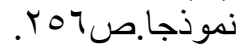

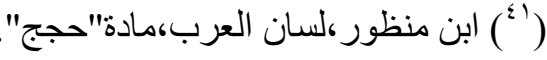


اصطلاحا:"الحِجاج هو كل منطوق به موجه إلى الغير لإفهامه دعوى مخصوصة يحة يحق

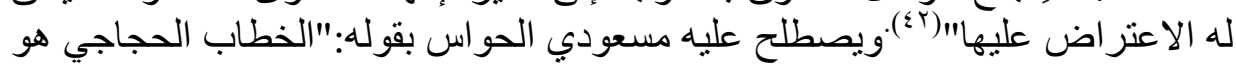

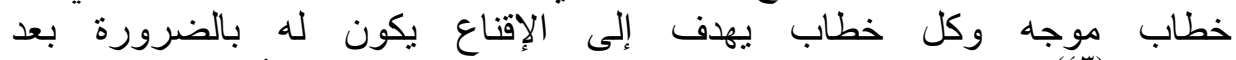

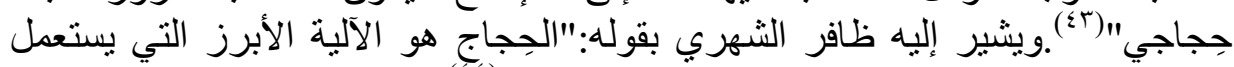

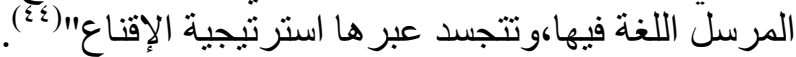

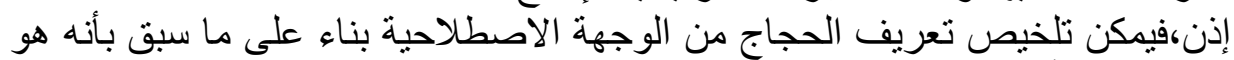

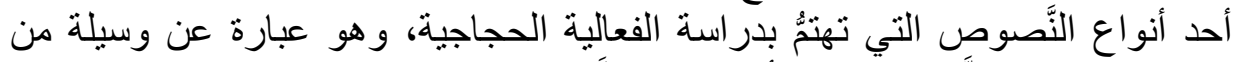

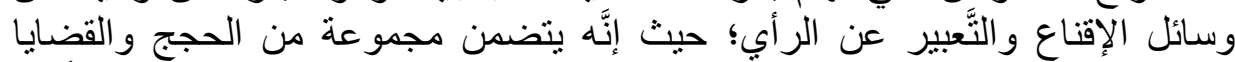

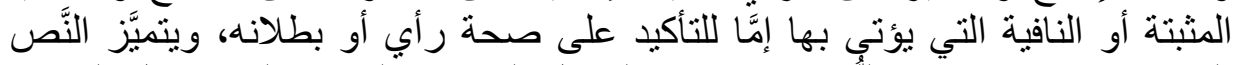

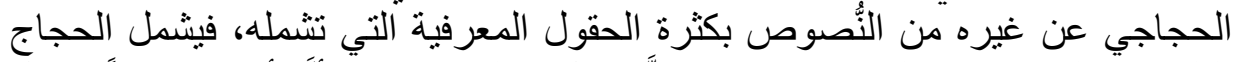

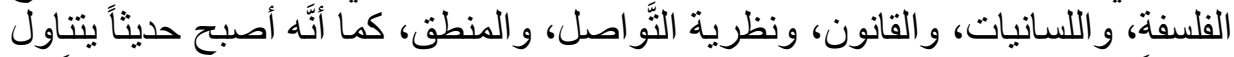

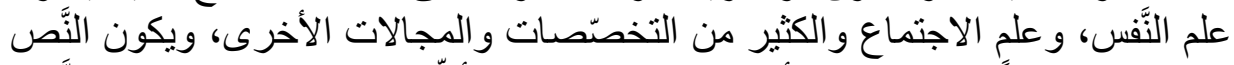

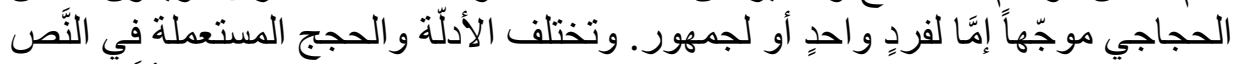

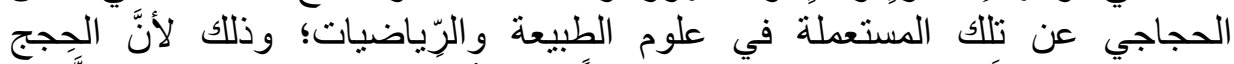

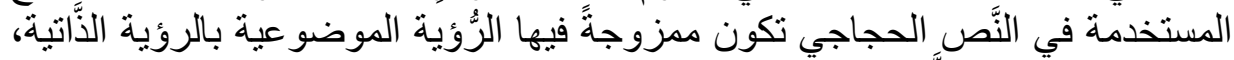

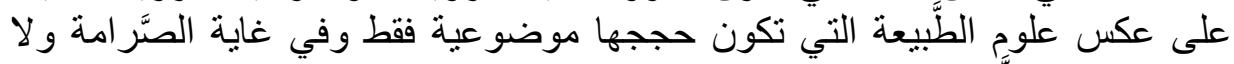
تحتمل الرؤية الذَّاتية.

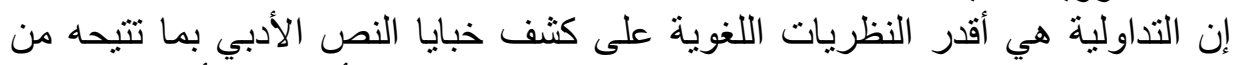

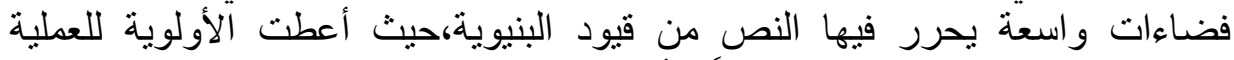

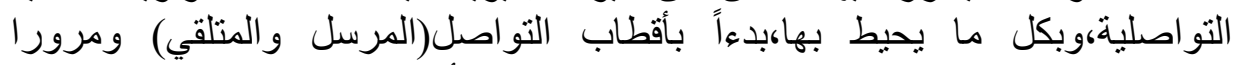

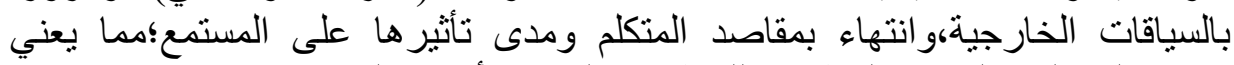

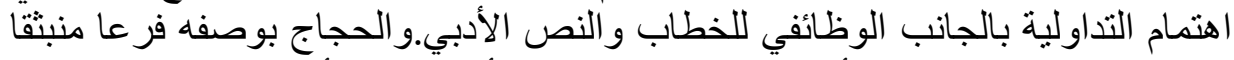

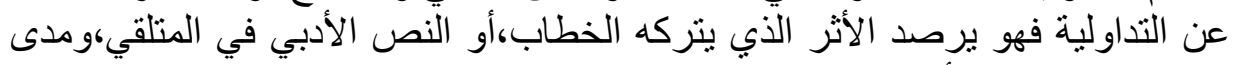

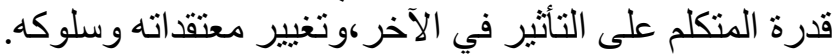

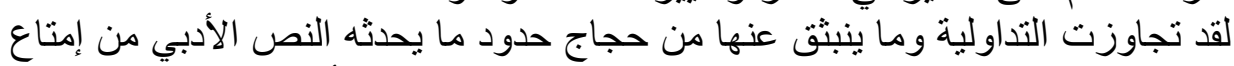

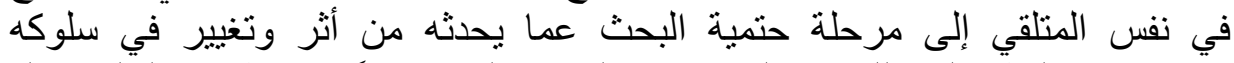

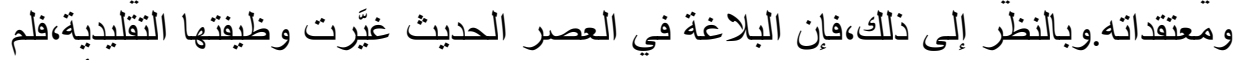

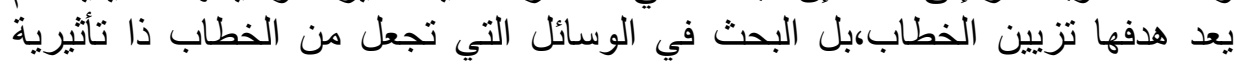

(r)

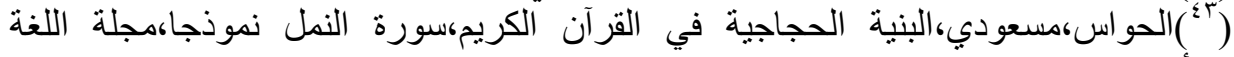

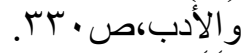

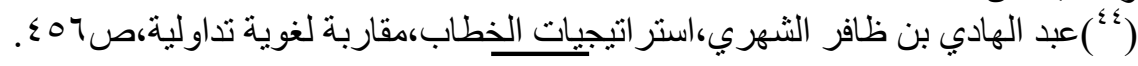




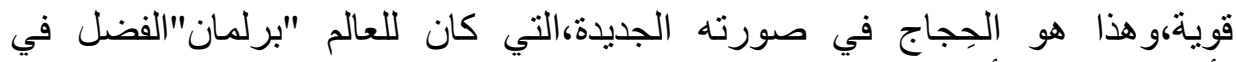

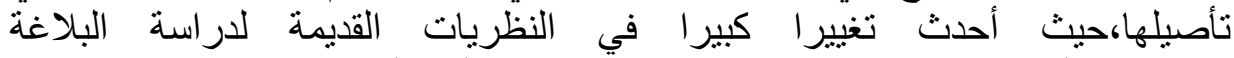

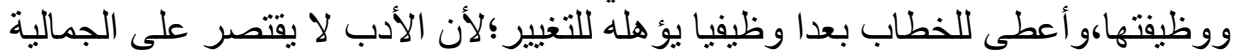

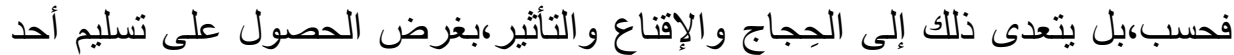

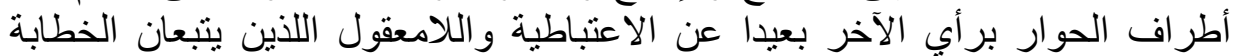
عادة،وبعيدا عن الإلز أم الذي الإي يتبع الجدل دائما.

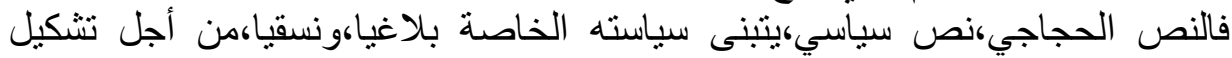

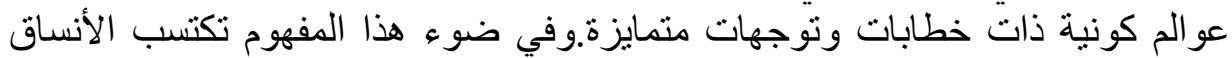

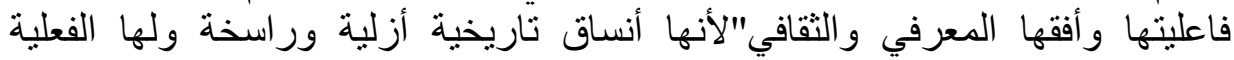

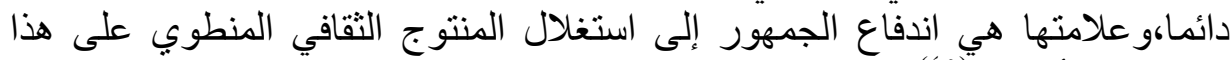

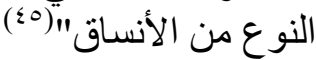
وتتنوع وسائل وتقنيات الحجاج فتارة تكون أدوات لغوية،واتوأحيانا بلاغية،وأخرى منطقيةًاو فلسفية أو قياسية. أمثلة لدراسة الحِجاج دراسة فئة تداولية: - البنية الحجاجية في مقامات الوهية هراني_هجيرة حاج هنىـ ماجستير جامعة حسيبة بو

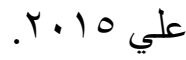
- - الحجاج في رسائل الثيخ أحمد التيجاني-ماجستير -أمينة تجاني-جامعة حمه لخضر

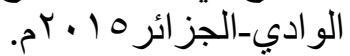
- مصطلح الحجاج بو اعثه وتقنياته_عباس حشاني،جامعة يسكرة-الجز ائر. - - بلاغة الحجاج في النص الثعري-دالية الراعي النميري نموذجايوايوسف محمود عليمات. النتائج والتوصيات وبعد فقد انتهى البحث في نظرية بلاغة الجمهور الجديدة التي تبناها الدكتور عماد عبد إنبان اللطيف، واستطاع أن يصلّ إلى النتائج التالية:

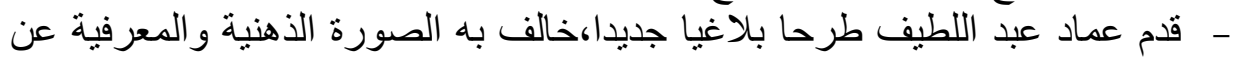

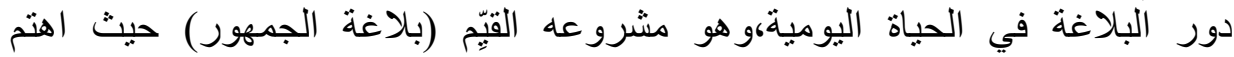
المشروع بالطرف المفعول به في العملية التو اصلية.

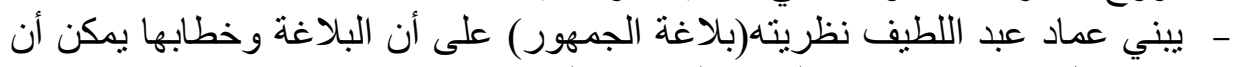
يؤثرا ،بشكل كبير ، في توجيه الوعي الثعبي و الجماهيري.

( ) الغذامي،عبد الله،النقد الثقافي:قر اءة في الأنساق الثقافية العربية.ص9 V. 
- - إن موضوع بلاغة الجمهور إنما هو الاستجابات التي تصدر عن الجمهور أثناء تلقيه

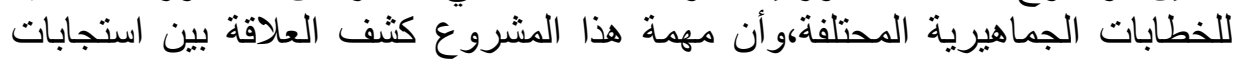

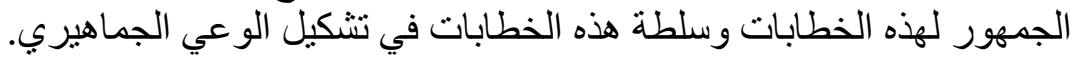

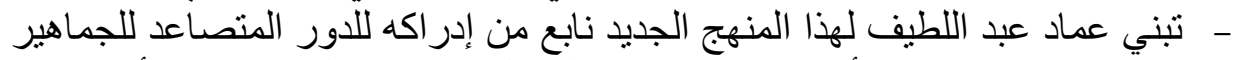

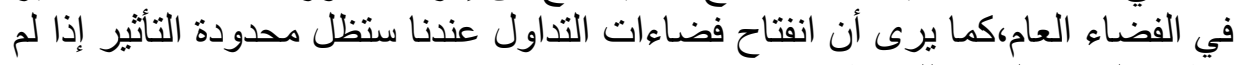
يتظور الوعي النقدي للمواطن.

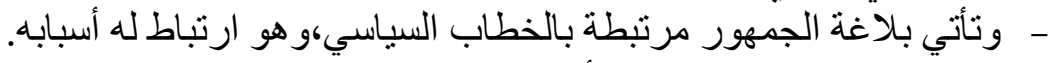

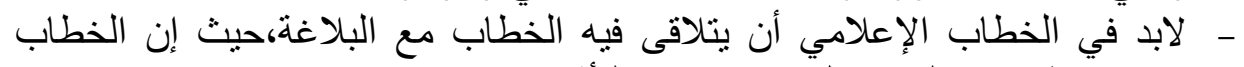

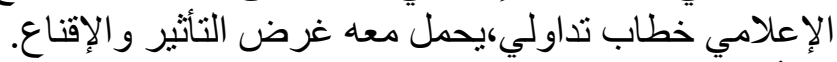

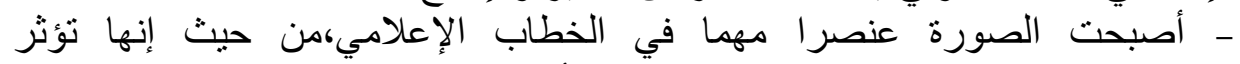

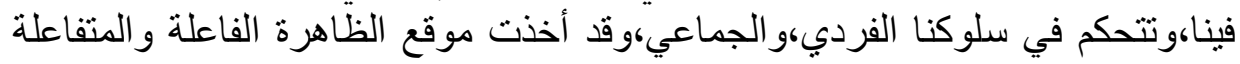

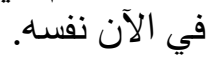

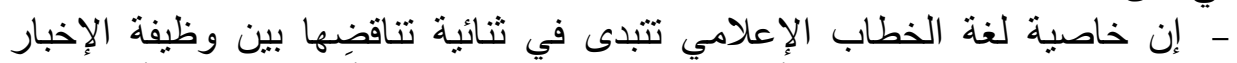

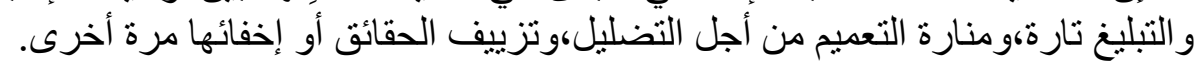

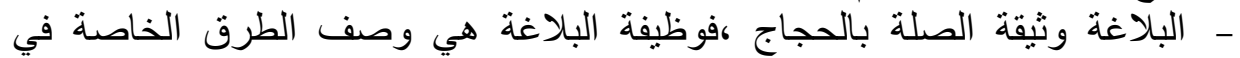

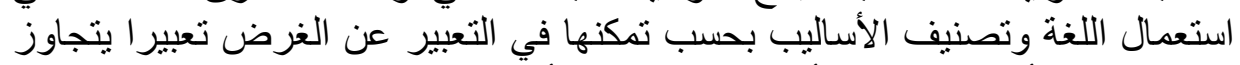

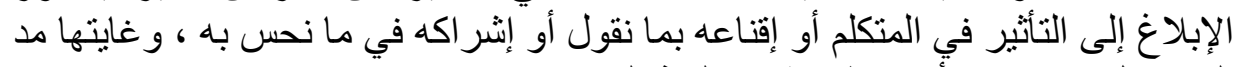

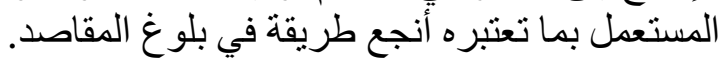




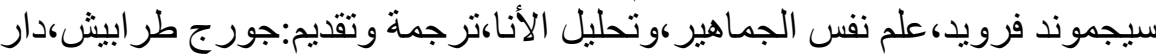

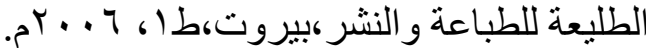

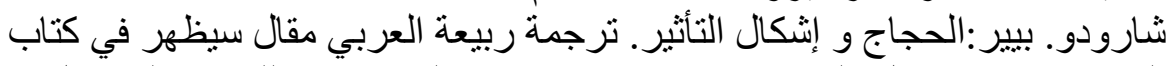

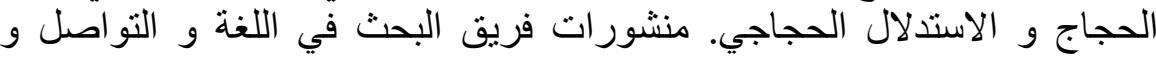

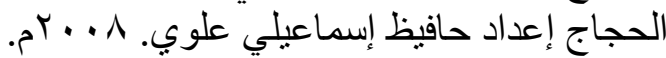

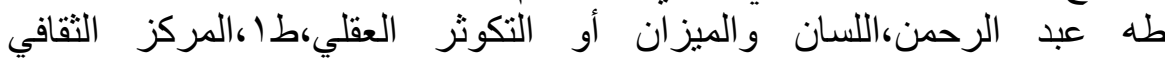

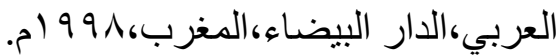

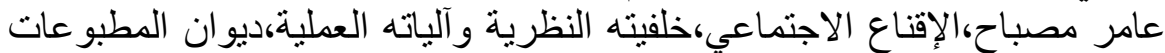

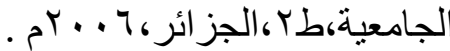

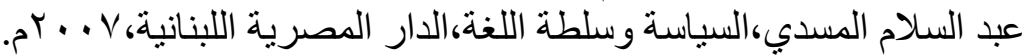

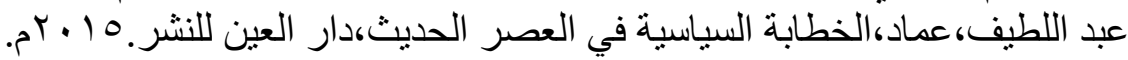

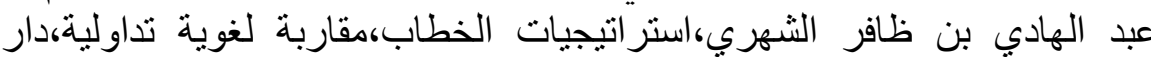

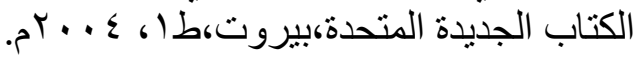
عماد عبد اللطيف استراتيجيات الإقناع والتأثير في الخطاب التهاب السياسي.). العيئة

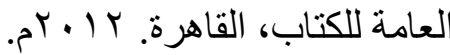

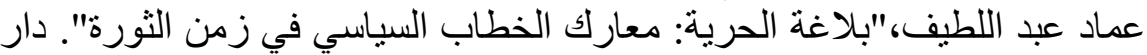

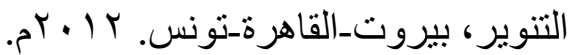
عماد عبد اللطيف،البلاغة والتوانوة الصل عبر الثقافات. سلسلة كتابات نقدية، الهيئة

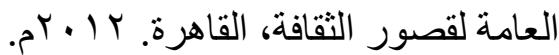

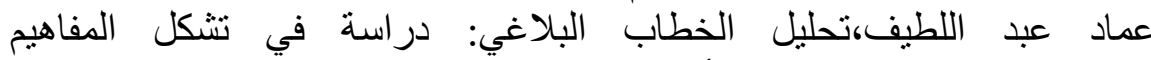

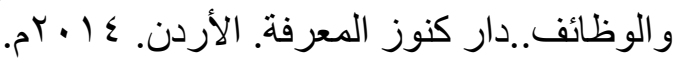

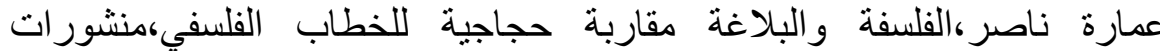

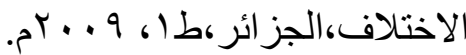

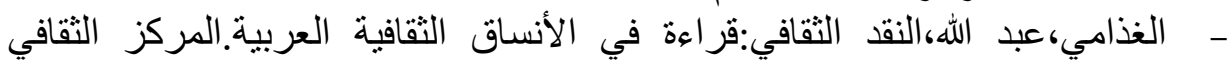

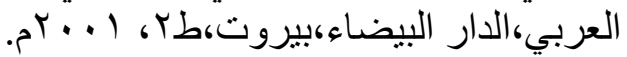


- - الغذامي،عبد اللهاثقافة تويتر:حرية التعبير أو مسؤولية التعبير،المركز الثقافي

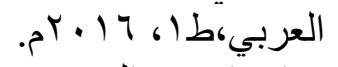

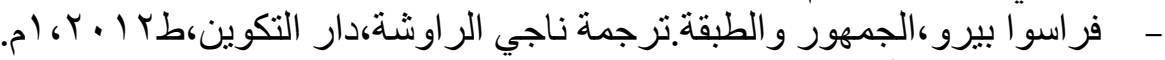

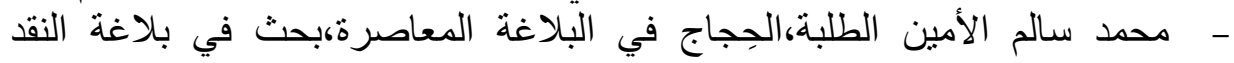

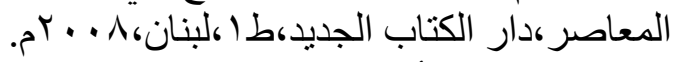

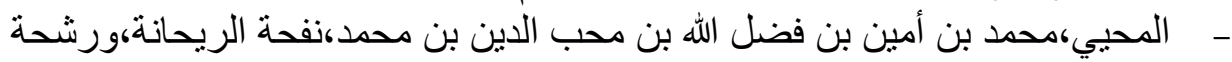

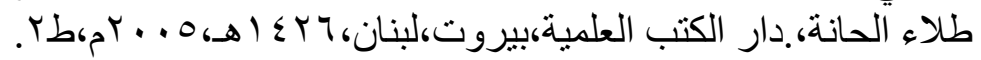
الدوريات والمقالات الدات دات

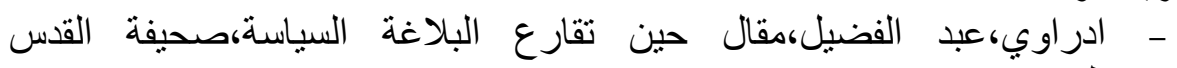

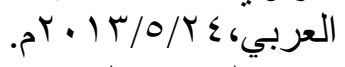

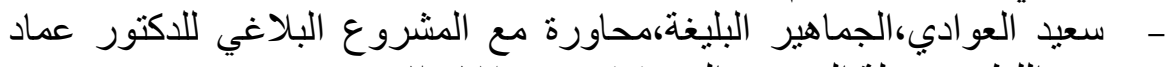

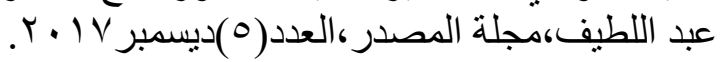

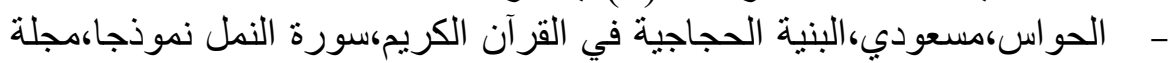

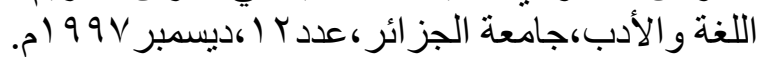

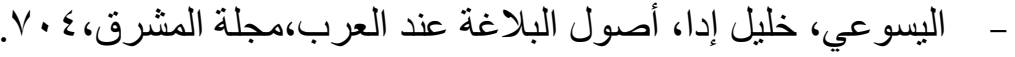

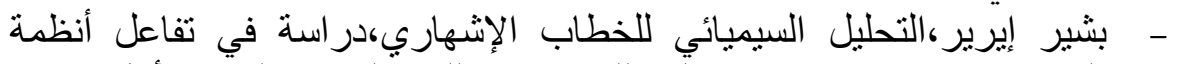

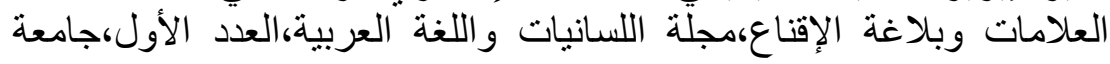

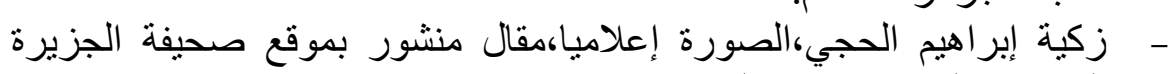

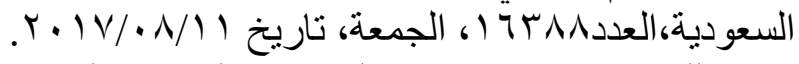

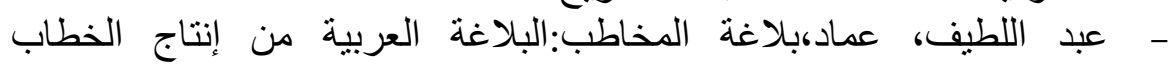

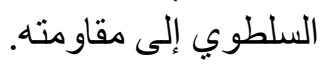

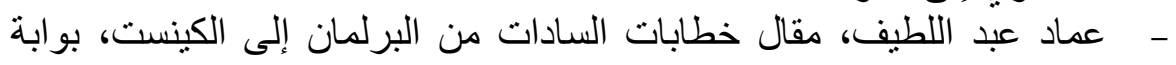

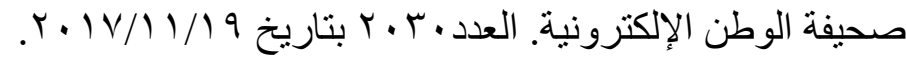

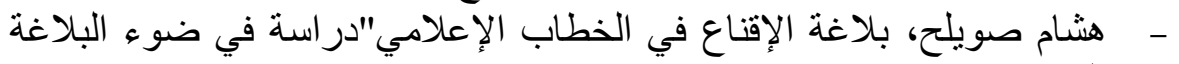
الجديدة. جامعة سكيكدة.(د.ت).

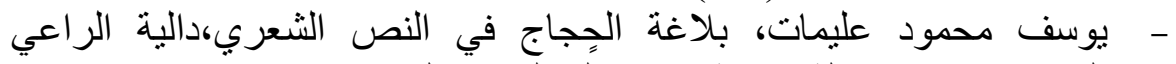

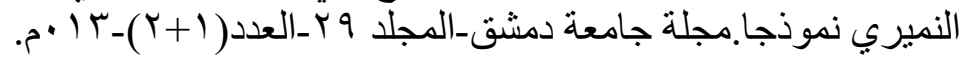


Doi: $10.12816 / \mathrm{mdad} .2020 .122951$ د. درجب إبراهيهرأحمل عوض 